CIHM

Microfiche

Series

(Monographs)
ICMH

Collection de microfiches (monographies)
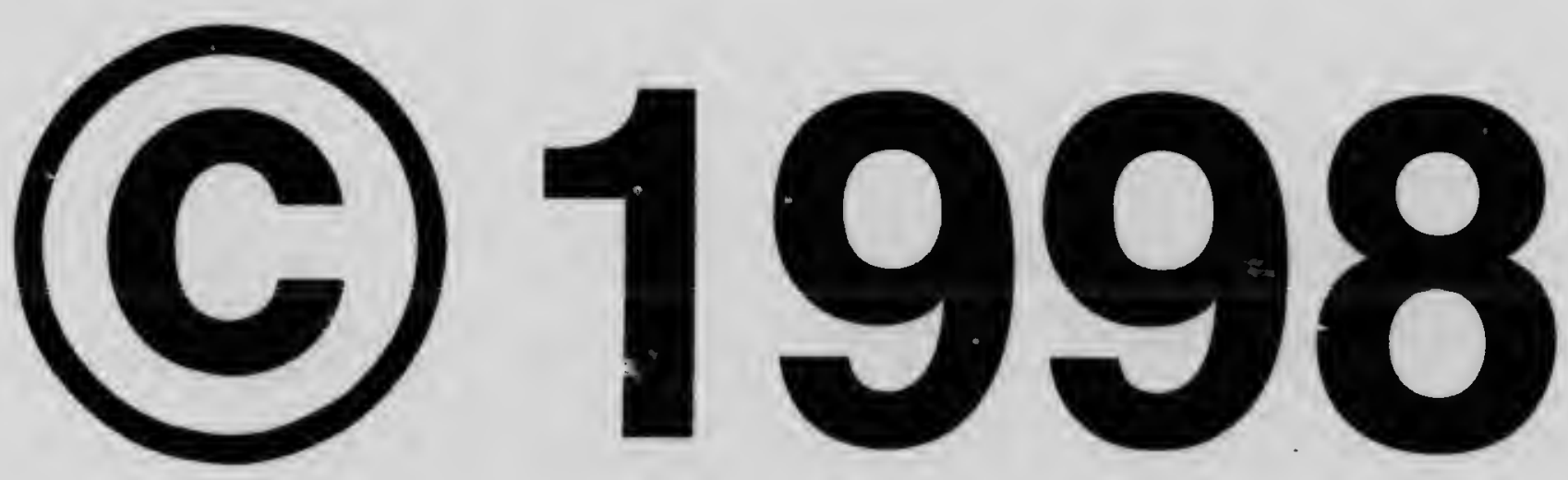


\section{Technical and Bibliographic Notes / Notes techniques et bibliographiques}

The Institute has attempted to obtain the best original copy avallable for filming. Features of this copy which may be blbllographically unlque, which may alter any of the images in the reproduction, or whlch may slgniflcantly change the usual method of filming are checked below.

\section{Coloured covers /}

Couverture de couleur

\section{Covers damaged /}

Couverture endommagée

Covers restored and/or laminated /

Couverture restaurée eVou pelliculée

Cover title missing / Le titre de couverture manque

Coloured maps / Cartes géographiques en couleur

Coloured Ink (i.e. other than blue or black) /

Encre de couleur (i.e. autre que bleue ou noire)

Coloured plates and/or illustrations /

Planches eVou illustrations en couleur

Bound with other material/

Relié avec d'autres documents

Only edition available /

Seule édition disponible

Tight binding may cause shadows or distortion along Interior margin / La reliure serrée peut causer de l'ombre ou de la distorsion le long de la marge intérieure.

Blank leaves added during restorations may appear within the text. Whenever possible, these have been omitted from filming / II se peut que certaines pages blanches ajoutées lors d'une restauration apparalssent dans le texte, mais, lorsque cela était possible, ces pages n'ont pas été filmées.

\section{Additional comments /}

Commentaires supplémentaires:
L'Institut a microfilmé le meilleur exemplalre qu'll lul a été posslble de se procurer. Les détails de cet exemplaire qul sont peut-être unlques du point de vue bibllographlque, qul peuvent modiller une image reproduite, ou qui peuvent exiger une modification dans la methode nomale de filmage sont Indlqués cl-dessous.

Coloured pages / Pages de couleur

\section{Pages damaged / Pages endommagées}

Pages restored and/or laminated /

Pages restaurées eVou pelliculées

Pages discoloured, stained or foxed /

Pages décolorées, tachetées ou plquées

Pages detached / Pages détachées

Showthrough / Transparence

Quality of print varies /

Qualité inégale de l'impression

Includes supplementary material /

Comprend du matériel supplémentaire

Pages wholly or partially obscured by errata slips, tissues, etc., have been refilmed to ensure the best possible image / Les pages totalement ou partiellement obscurcies par un feuillet d'errata, une pelure, etc., ont été filmées à nouveau de façon à obtenir la meilleure image possible.

Opposing pages with varying colouration or discolourations are filmed twice to ensure the best possible image / Les pages s'opposant ayant des colorations variables ou des décoloratlons sont filmées deux fois afin d'obtenir la meilleure image. possible.

This item is filmed at the reduction ratio checked below I

Ce document est filmb au taux de ríduction indiquó ci-dessous.

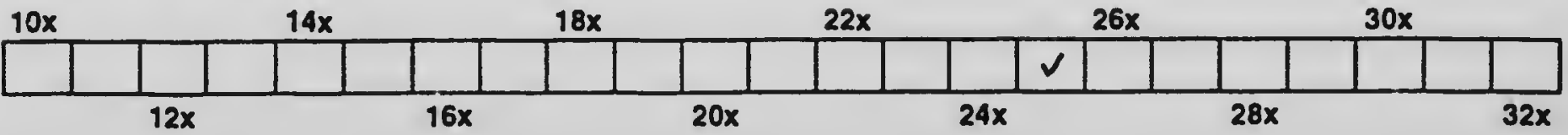


The copy filmod hore has been reproduced thenks to the eencreairy of:

\section{Mational Ifbrary of Canada}

The imeges appeoring here ore the best quoijty possible considering the condition and legibility of the original copy and in keopling with the fllming eontrect spoeiflestions.

Original copiee in prinsed pepor covore are fllmod beginning with the tront cover end ending on the last poge with e printed of llluetrated impres. slon. or the beck cover when eppropriots. All other origlnal copies are filmed beginning on the flrse page with e printed or lllustrated imprestion. end ending on the last pege with e prinsed or lllustresed Impreasion.

The lest recorded freme on each microflehe shall centain the symbol $\rightarrow$ Imoening "CONTINUED"), or the symbol $\nabla$ (meening "END"). whiehever applies.

Maps. plotes. chorts. otc.. mov be filmod at different roduction rotios. Those soo lerge so be entirely included in one exposure ore filmed boginning in the upper lote hand cornar, lott 80 right and top to botzom. as many fremes as required. The following diegrems lllustrete the merhod:
L'oxomplaire fllm fut roproduit ortce of is gindrosizs do:

\section{Bibliothique nationale du Canada}

Les images suivantes one ded reproduites ovec lo plus grand soin. compro ronu do lo condition at do lo motrots de l'oxemplaire fllmb. ot on conformité avec les conditicrs du controt de tiimage.

Les examplalres orlglnaux dont 10 couverture en papler eat Imprimbe sont fllmbs en commencent par lo promlor plot ot en terminant solt per lo dernibre page qul comporte une emproinse d'impresslon ou d'illustration, soit par lo socond plat. solon lo ces. Tous los ourres exemploires orlginaux sont fllmbe en commençant par la premidre poge qul comporte une emprointe d'impression ou d'lllustrotion of on terminent pap la dernibre page qui comporto une tollo empreinto.

Un des symboles sulvents apparaitre sur lo dernibre imege de chaque microfleho, salon to cas: 10 symbole $\longrightarrow$ slgniflo "A SUIVRE". 10 symbolo $\nabla$ signifio "FIN".

Les cones. pienchos, tableoux, otc.. peuvent ótre filmse des taux de idduction difforants. Lorsque bo document ast trop grand pour btre reprodult en un saul clleht. II ast filmb \& pertir de l'engle supdrieur gouche. de gouche defoire. ot de hout on bes. on prenent lo nombre d'Images ndesesealro. Lee disgremmos suivants Ullustront la motnodo.
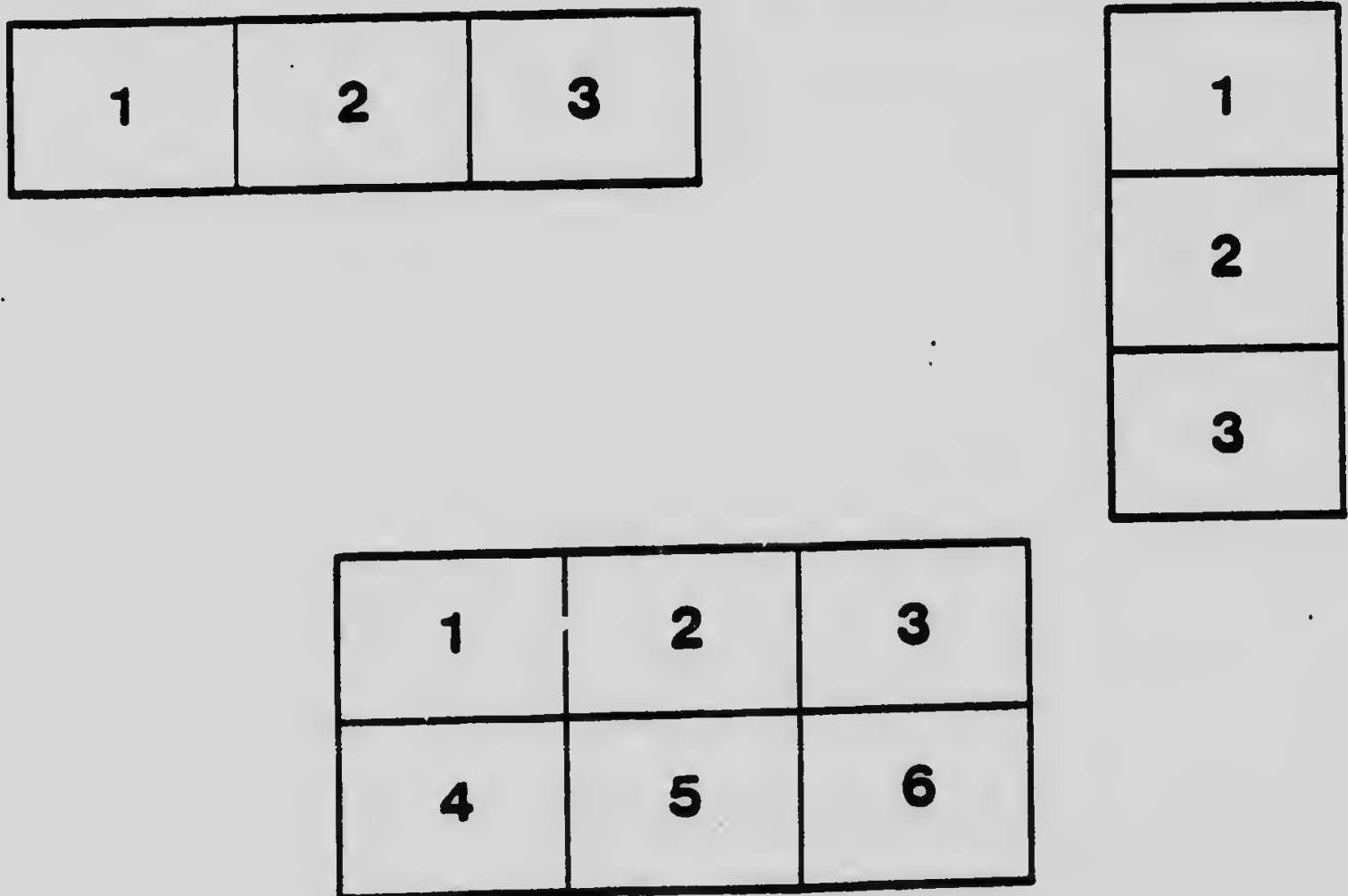
Marocort Resolution tat CHARt

(ANSI and ISO TEST CHART No. 2)

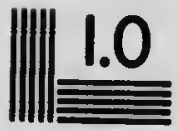

\begin{tabular}{lll}
43 & 2.8 & 2.5 \\
\hline 30 & &
\end{tabular}
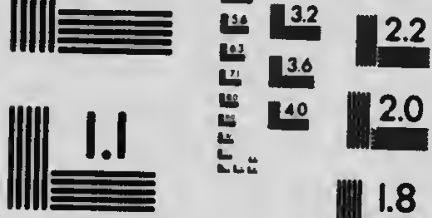

논 2.0

ㄴ.
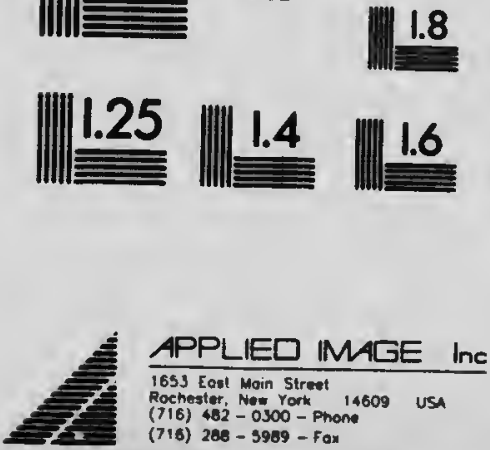


\title{
SPECIAL REPORTS
}

ar

\author{
PR0FESS0R EDWARD E. PRINCE, F.R.S., Canada
}

Dominion Commissioner of Fisheries, General Inspector of Fisheries, and Director of the Biological Stations of Canada.

I. THE LOCAL MOVEMENTS OF FISHES.

II. U.UTILIZFD FISHEKY PRODUCTS IN CANADA.

\section{7}

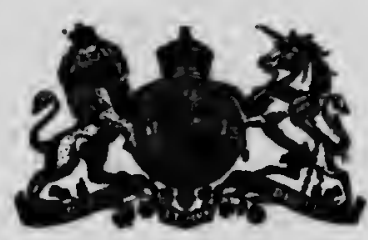

OTT AWA

GOVERNMENT PRINTING BUREAU

1907 


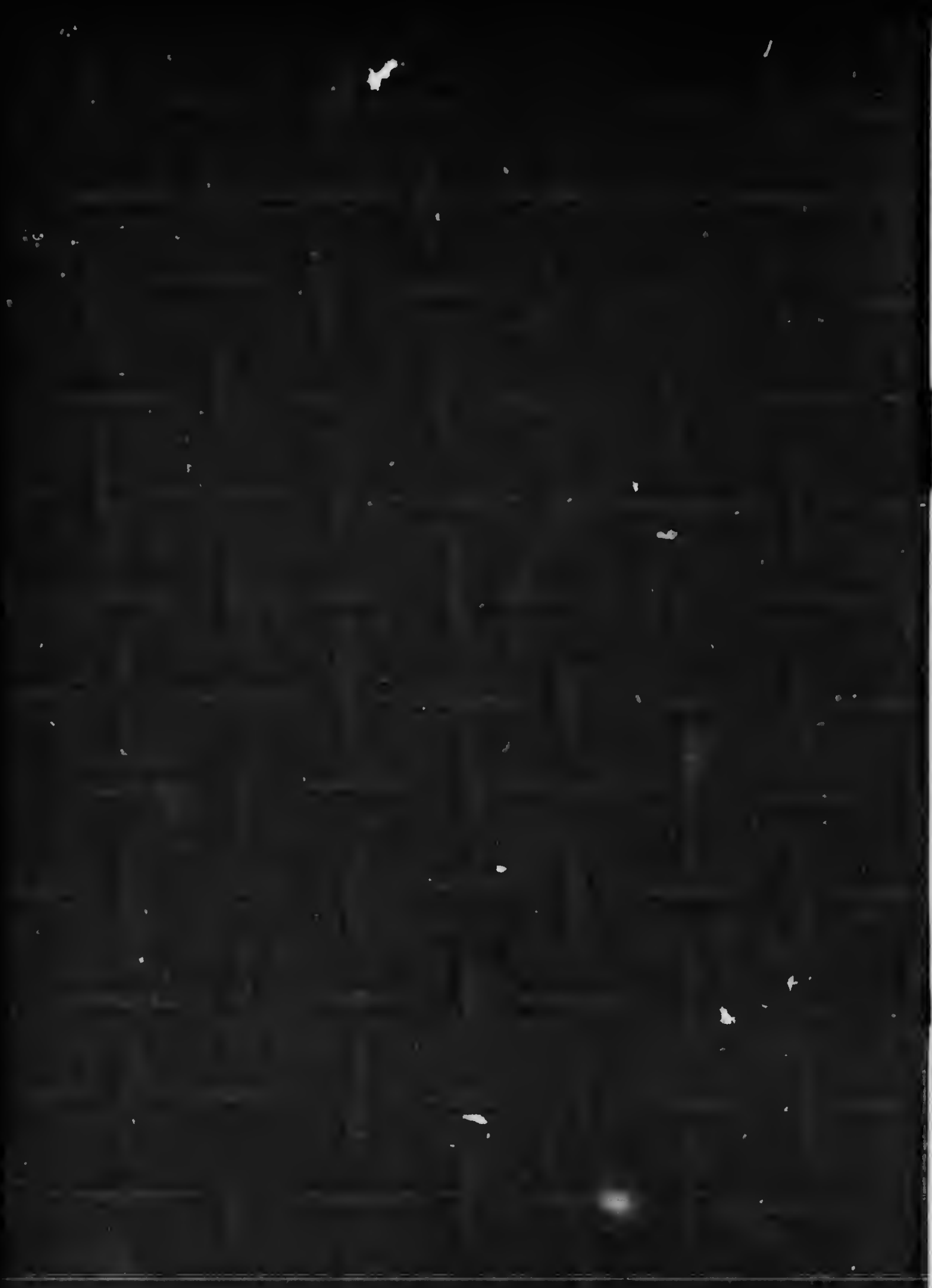




\title{
SPECIAL REPOR'TS BY
}

\author{
PROFESSOR EDWARD L. PRINCE, F.R.S., Canada \\ Dominion Commissioner of Fisheries, General Inspector of Fisheriss. and l)irector of \\ the Biologionl Stalions of Canada.
}

I THE LOCAL MOVEMENTS OF FISHES.

1I. UNUTHLIZED FISHERY PRODUCTS IN CANADA.

\section{7}

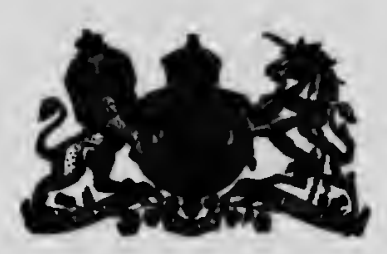

OTT A W A

GOVERNMENT PRINTING BUREAU 1907 


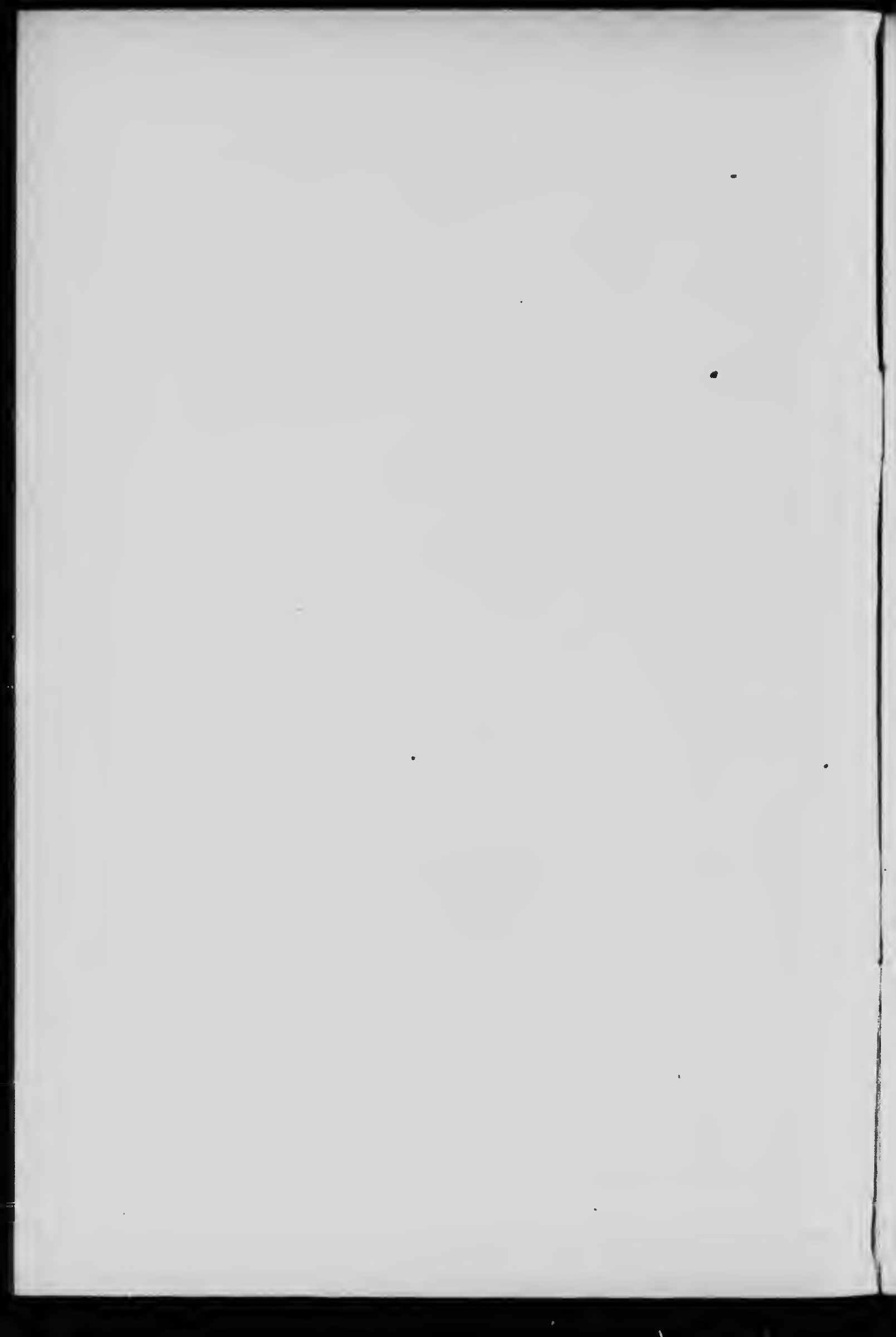




\section{CONTENTS}

\section{I.-TIE LOCAL MOVEMENTS OF FISHES.}

Alleged uncertainty of fishes' movements-Two supposed causes of migrationFishes move with fixed regularity-Practical bearing of queation-Fry migratio 1s-Professor MoIntosh's great discoveries-Persistent habits of young fish - Studie on flat fish (plaice)-Marking fish inconclusive-Local varieties imply limited migrations-Fishes are true to their routes-Migrations not always at spawning timo-Utility theory inapplicablo-Past subsidence of sea important-River basins once part of sea-Hardships of migrating valmonMany salmon dio-Land-locked varieties of sea-finh-Heredity is the causoSome fishes nou-migrntory-Summary. pp. 1 to 12.

\section{4.-UNUTILIZED FISHERY PRODUCTS IN CANADA.}

Introduction-How product are wasted-Reprehensible methods of utilizationBest products essential-Known neglected resources-Foreign fish products instructive-The carp-Improved methods of utilization urgent-cured versus fresh herring industry-Ontario cured herring impossiblo-Tunny industry possiblo-Sknte, dogfish, shark's fins, \&c.-Roe of fishes-Sea cucumber or Trepang-Abalone and other mollusks-New bait resources-Sea-weeds, \&c., for chemicals, food, bedding, \&c.-Corallines and sea-weeds for decorationEel skin industry-Fish and sea-weed glue, isinglass, ec.-Shell, button, and pearl industries-Piawns, shrimps and crayfish-Skins of fishes, whales, bc. -Ice industry suggested-Conclusion. pages 13 to 34 . 
 \\ THL LOCAL MOVEMENTS OF FIBHES. \\ By Protranon Eowand E. Paisce, Dowinion Commualonza or Fianeajes, Cuajaman or tux Butrun Columeia Fishenten Comyianos 1905-1907.}

The belief long provailed, and even now has wide currency, that fabes in the nea, or in lakes and rivers, are comewhat erratio and uncertain In their movemente. It was admitted that the mierating schools of aclmon showed recularits in the periods of thelr acent of rivers, and had more or less fixed courmen, while the vant armies of herring,

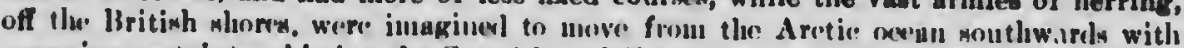
unerring certainty, akirting the Scottish and Engliwh cuasto, to dienppear in the depthe
of the sea.

\section{ALLEGED UNCEATAIN MOVEMENTS OF TISH.}

These two examples of regular and onder 1 migration were however held, by fishermen and authoritie in general. only to emphasize the ceneral feature of fortuity in the wanderings of the finny tribes, hy their exceptional character.

To the scientific mind, there appeared something Incongruous in this alleged erratic and aimlons migritiou. The order of unture is much that the liver of animuterl things, even man himaelf, are circumscribed by conditions and unalterable laws, and the migratory habits of fislies could harlly be an exception. The purnuit of fishing has always appeared one of the most uncertnin rosible. and this uncertainty in the capture of Gish seemed to support the theory that no regular laws, or well-orrlered conditions, governed the movements of the inhabitants of the deep.

\section{TWO BUPPOBED CAUES OF MURATION.}

Two causes, it is true, were reganded as most potent in stimulating and directing the course of fish. viz.: the search for food, and the search for suitable apawning grounds. But while there is some foundation for this view, yet it will not, in strictness, apply to most cases, for appropriate food is very widespread, and not limited to aperial locylitiex. onnitting eertain very exceptional instances, while the cliacoverios of science in recent rears have shown that the spawning procen might bs appropriately performed in almost any area through which migrating schools of fish may pass.

\section{FISHES MOVE WITH FIXED REOULARITY.}

Far from being errutic and wholly uncertain, the migrations of fishes exhibit in general the most astonishing regularity, and so tive may they be to their particular migratory course, and to the period or, it may be even said, the exact date of their appearing, that some profound cause is evidently at work; some cause more potent than the search for a favourite feeding ground, or for an aceustomed spawning resort. The purpose of this brief report is to show what this profound cause is, and to indicate some of the complex features which modern scientific studies upon fish life have revealed.

$$
\rightarrow 30 t ;-2 \cdot 3
$$


PRACTICAL BEARINO OF THE QLESTION.

The subject is one of great practical moment, for the determination of wise preservative measures, and of appropriate fishery legislation, and even of far-reaching interuational fishery policy, depend upon an aecurate kuowlerge of this subject, viz.: the real character of the movemerts of the schools of fishes in their native waters.

\section{MIGRATIONS OF FRY.}

The migratory movements of fishes begin immediately after they leave the egg. In fresh water the young hide in pebbly rough ground at the bottom, and move into sinooth sheltered shallows, as soon as they are strong enough to swim with some vigour. At first they are weak, and in most cases swim with difficulty, owing to a large sac of food yolk attached to the underside of the body. In the sea, the yolk-sac may act as a float and the young fish wriggles along in a reversed attitude, back downtrards. The fine-meshed tow-net of the naturalist captures immense numbers of these small ncwly hatched fish which abound within a fathom or two of the sea's surface.

\section{PROFESSOR AICINTOSII'S GREAT DISCOVERIES.}

Thanks to marine biologists in Norway, Britain, France, Germany, the United States and Italy, a large mass of information is now available regarding the cggs and early life-history of marine fishes; but no researches compare for extent and value, with those of the famous Scottisl zoologist, Professor McIntosh, whose investigations have beell recognized in all countries for nearly 30 years as the most important and valusble of all. His scientific reports on fish-life in the North sea, were mullished in the Royal Commission's Report on Trawling, London; 1884. Professor McIntosh's were the first systematic studios actually carried on upon fishing boats and tugs out in the sea, and in experimental tanks at the marine laboratory, St. Andrews, with the ohject of deciding the spawning habits, nature of the eggs, character of the young, and their migrations in the sea. These studies have been carried on continuously to the present time.

\section{PEI.SISTE:TT IIABITS OF YOLYG FISII.}

The migrations differ somewhat in various species, but their ascent or descent vertically, or their movement from shallow to deep water or vice versa, have been proved to be as certain and unehaugenble as the seasonal travels of migratory birds. Storms. winds, dc., inay delay or even divert them somewhat, but their courses on the whole are fixed and unfailing. Thus the young cod'says Professor McIntosh in a recent address," the green cod, haddock, and whiting, after their earliest (larval) stage, are oblivious of currents in their movements-on the one hand to shallow, and on the other hand to deep water, and the same may be said of the young flat-fishes. There is no reason to belicve that the hardy adults are affected by temperatures, currents, or salinity in a greater degree, cxcept in so far as storins may sweep into bays greater quantities of food.'

\section{STUdies oN Flat fish (THE PLAICE).}

The plaice which is one of the most abundant and raluable of European flat-fishes has usurped a large amount of attention since its eggs were first hatched and its stages of growth to the edult condition studied, and figures drawn at St. Andrews, Scotland. Other younger workers have since then published results, in later reports, but they are singularly at variance. 'Dr. Bolan, the German experimenter' as is pointed out in

\footnotetext{
"Two lectures 'Scientific Work in Sea Finheries, liosal Inst.', London, May, 1907.
} 
the Royal Institution lectures already referred to, ${ }^{*}$ differs from Dr. Garstang, the former stating that plaice leare the consts in summer and autumn, and return in spring, whereas the latter gives spring and summer as the period of migration to the off-shore. Here, then, is considerable variation in the results, and neither agrees with the condition at St. Andrews. Many supposed phenomena of migration are found to he outside the regular movements of the fishes referred to, while the alleged scarcity of disappearance of fish, espeeially in the sea, may be duc to defective means of eapture, e.g. the beam trawl or an unattractive bait. Certain obs'rvers, under the Scottisli Fishery Board, reported the disappearanee of plaice from their haunts, but as Dr. II. M. Kyle has shown the introduction of a plaiec-seine from 18i2-1830 in Danisl wateris trcbled the eatches in supposed depleted areas. The use of a new bait, viz.: an aetinian or anemone instead of the usual unussel bait, revealed the presence of abundant cod and haddoek. which were supposed to have deelined. The ordinary bait had lost its power to attraet them.

\section{MIGRATOXS OF MARKED FISII INCONCILSWE.}

Expcriments with marked fish in the sea have proved most inconclusive. A far safer fuide is the eourse taken by the practienl fisherman, whose living depends upon

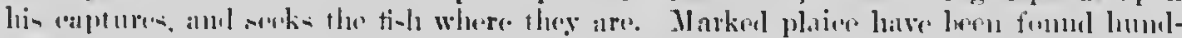
rels of niles from the spot where ther were liberated. May it not be tlut like the 'Rat with the bell' in the old story, or the dog with the kettle tird to its tail, thewe fish earrving an irritating plate, or wire, or other mark. beliaved in an abnormal and

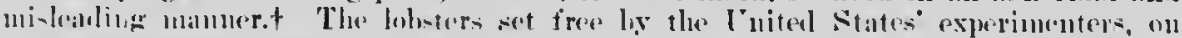
the Massnehusetts shores, which wandercd orer a lundred miles, cannot be taken as proof that the vast hordes of Canadian and United Stntes lobsters perform seasonally

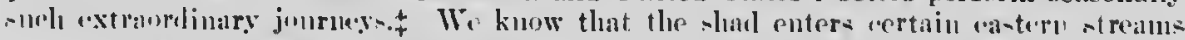
on our Atlantie eonst, evidently eoming in from no very distant plaees in the open sca, yet the shad planted in Oregon were found to have wandered 400,500 and ercn 1.000 miles, two speeimens being enptured, as carly ns 1895 , at Rivery inlet, at least , 0 miles from the place of liberation. Jany, too, have entered the Frnser river.

\section{LOCAL VARIETIES IMPLY I.IMITED MIGRATIONS.}

There is abundant eridence that fish have their own resorts, and adhere to their own nigratory courses. An expcricnced salmon fisherman ean readily determine from what river a certain salmon has been taken. A Godbout (Labrador) snlmon ennnot be confused with a Restigouche fish, or the latter identified with a Miramichi or St. John

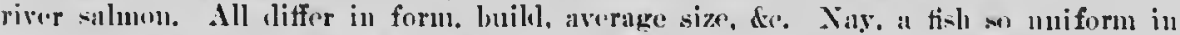
size as the soekeye or bluebaek salmon (O. nerka) of the Pacifie eonst, shows similar lncal peculiarities. A Rirers inlet sockeye is of larger size, it is claimed, than a Fraser river fish, while the red flesh is paler than that of the soekeye of the Nimpkish rives, only 40 or 50 miles away. The Nimpkish salmon average, one important eanner said, 16 to a case (48 lbs. weight) though an exceptionally large sockeye was taken in that river, in 1895, for $10 \frac{\mathrm{z}}{2}$ to $11 \frac{1}{2}$ salmon filled a case of canned fish. Further, it is said that in the same river, partieular 'runs' make for specified tributaries or upper waters. 'I can tell a Harrison river soekeje,' said a pioneer salmon eanner on the Fraser river; yet there are at least seventy-five tributaries of the Fraser river to which

- Lecture II., p. 8, reprinted from the Zoologist, 1907.

+ In the Iancashire Sea Fisheries Labora tory Report, 1907, p. 128, Mr. J. Johnstone, that in some species the flesh is chafed and a bar wound caused by the marked label.

I Dr. Mlex. Meek says in his report on 'Migratlons of Crabs' that trom the records it is shown that "the males may remain in the same region for soreral years." S.i. Invest. Northumb. See Fish. Rep., 1906. 
the salmon schools ascend for spawning purposes. A similar statcinent may be made in regard to the sea herring, of which the Loch Fyne varicty has long been generally recognized. On the great lakes the common whitefish (Coregonus) exhibits distinetive differences in cach of there vast areas. All these facts go to slow low emphatically local a great many species of fish are, and that even so typical a migratory fish as the sea herring is confined to comparatively narrow limits, the schools in each locality, moving in from the deep water and back again to these feeding grounds, without wandering very far from their native area. There are exceptions to which I shall make reference on a later nage.

\section{FISI ARE TRUE TO THEIR MIGRATION ROUTES.}

Not only have the fishes, in sea and fresh water alike, their own local habitats, but ther adhere very strikingly to their own routes in moving over their restricted areas. It is well known that fish-traps and other nets, set in a particular spot, will make large captures, hecause the schools habitually pass that apot, whereas a net placed close by, but just off the specified route, will make poor captures or even take none at all. It has long been known, on all salmon rivers, that the schools have a very definite course, and while winds and tides, storms and currents, may cause modifications, these changes are subordinate and do not affect the general law. The English Severn, as I have mentioned in previous reports, possesses tributaries which to all appearance are as suitable as auy others, yet the aalmon never ascend them. It is true of all salmon rivers. Such a river as the Skeena, in northern British Columbia, has comparatively few tributaries (as compared with the Fraser), but the main schools (i.e., the sockeje salmon) adhere to certain tributaries only and will not go up all alike. Indeed, they prefer the upper Babine tributaries, to reach which frightful canjons, terrible rapids, and every kind of deterrent, must be overcome; but the neurer casicr tributaries cannot tempt them to cnter. The immense armies of Fraser river salmon, moving along the Juan de Fuca straits, will not turn aside, though numerous suitable and more accessible spawning ground occur on Vancouver island, such as those up Clayoquot sound, \&c. As a prominent Clayoquot salmon packer said of the small schools which passed his locality: 'I thought that these fish were on their way to the Fraser and that we only got a wing of these schools that swung into our sound, but the longer I stay there, the more I am convinced that they are peculiar to their localities. They seem to run regularly, and the big (Fraser) run does not affect them, which I think would be the noticcable feature if they were in any way connected with the Fraser river run." Not only is this the case, but the salmon on reaching the upper waters, when a fork occurs in the tributary up which they are moving, will unfailingly select one fork or branch, season after season. In the Nicola ralley there is a salmon stream which divides into two owing to an island in midstream, and across the left channel a barricade was built for lumbering purposes. The salmon could not surmount the barricade, but they would not ascend the right or open channel. The local Indians said: "The salmoil know their way and that right channel is not their channel.' The bands of Indians above could not get their food supplics of salmon and complained bitterly. Certainly in large estuaries like the Bay of Chaleurs, the salmon moring into the famous Restigouche river prefer the southern or New Brunswick shore, and the aalmon nets on the Quebec or north side are therefore few, and their catches have always been smaller than on the opposite ahore.

\section{MIGRATLONS NOT ALWAYS AT SPAWNINO THIE.}

While fish, as a rule, move in large schools as spawning time approachesł and anadromous species move into rivers yet there are regular migrations, which hare not

\footnotetext{
-At interrals orery fourth year is the popular view, the Sockeye Salmon run in ex. ceptional abundance up the Fraser river.

t There are exceptions. The Caspian herring. Clupea Kesslèri. Dr. Kousnetzofi, say. "remonte indiriduellement, et non par hancs, le haut Volga. \&c." Rep. Int. Congress Fish.
eries, Paris, 1900, p. 111 .
} 
this purpose. The smelt, for example, is a spring spawner and in March or April deposits ita eggs in brackish water near the mouths of rivers and in estuaries, but, in such a river as the Miramichi, immense schools of snelt- enter the river in November - and December. $\Lambda t$ that time enormous catches are made through the ice. Indeed the greatest catches of the year are then secured. So far as known there is no particular food at that time to attract them in, and thes are not approaching the spawning condition, which is attained four or five months later. Schools of sturgeon migrating from the sea have been similarly observed, long before their spawning period. Fraser river fishermen claimed that they came in after the smelt, in February, and fed upon them as voracious!y as the Labrador cod feed upon the smelt-like capelin (Mallotus) when these small fish approach the shore for spawning purposes. This early run of sturgeon was in February, 1895; but the great runs of these fish were in the fall in August, and later, when drift nets were used in the night at 'slack water.' Ten or twelve years ago I saw large runs of half-grown pikc (Esox) passing up small streams in the northern Saskatchewan district, northwest of Canadn. They were so numerous that I procured a number by striking them at random with a long pole, and they proved a weclome addition to our camp fare. The descent of eels, in large schools, down rivers is now understood, since it has been proved that these fish spawn in the sea. The young eels $3 \frac{1}{2}$ or 4 inches long ascend in spring some weeks after they have hatched out.

Now, while there is ground for the view that winds, currents and tides, and pos. sibly temperature, salinity. \&c., may affect the morements of fishes, there is no question that the cause of these migrations is more profound. Nor is it sufficient to say that it is of advantage to the fish to move, that they may escape enemies and other dangers, and that on the principle of the survival of the fittest, the kinds of fish that have adopted the migratory habit have survived. while those succumbed that did not do so. If this be true of the shad or the salmon why is it not true of the eel, whose young are hatched out in the deep sea, in the midst of those dangers which it is alleged the ehad and salmon escape by being hatched in fresh-water, more or less distant from the sea The newly hatched herring mounting to the surface of the sea and moving shorewards later ' to form' as Professor MeIntobli suy* 'a carpet on the sandy luys.' still unain. tains its amazing plenitude, while the migratory river herring known as the gaspereau or alewife, having acquired the habit of ascending the rivers to escape the sea's dangers, at the time of spawning, has decreased, and in some Canadian rivers has become almost extinct.

The real reason which prompts fish to migrate from deep water to shallow, or from the sea to remote fresh waters, or like the catadromous eel to descend to the sea for breeding purposes, must be sought in less obvious explanations than mere safety, or more favourable physical and biological conditions.

PAST SUBSIDENCE OF SEA IMPORTANT.

The researches of Dr. Oskar Grimm on the fishes of the Caspian sea no doubt furnish the key to the problem. There are five or sis species of lerrings in that sen, showing, as Dr. J. D. Kousnetzoff says, "l'mion qui existait à l'époque geologique trés eloignée de cette mer close uvee le bassin de la mer Surmate et pronve son origine communc avec la mer Noire et la mer d'Azow." Morenver, as this authority states, the herring in these sens, now no longer continuons, ascend thrir respective streans at the proper season to spawn. During the rest of the sear they monain in deeper water. where food is abundant. "La plus grande partice de l'anníe le hareng reste lans les profondeurs de la mer Caspienue," sars Dr. línusnetzoff. "ear il s'y trouve une aboudante nourriture dans la mase dos ctres vivants. eommengant par las erustacés et fuisseant par le poisson menu, Atherina caspir. Eichw. 


\section{RIVER BASRE ONCE PART OF SEA.}

It seems clear that the salmon, shad, alewife and other migratory sea fish, still resort to the regions (the upper waters and chosen spawning sites) to which their ancestors resorted, when thes? regions still formed part of the sca. As the land was elevated, and the more remote river basins were cut off, excepting by the narrow com. munications called rivers, the fish retained their liererlitary tendeney. This tendency, of ten named instinct, is so strong that all the endics obstacles to accomplishing the migration cannot deter thcm. Rocky canyons, rushing rapids and falls, landslides filling up river channels, predatory birds and aquatic mamrials, fishermen civilized and savage, bears, foxes, seals and all manner of enemies make war upon then. Man ereets dams and barriers or pollintes the waters with factory refuse, but the hereditary instinct is too strong to be crushed down.

\section{IIARDSHIl'; Of MIGR ITING SALMON,}

The tish take no food, they becone emaciated, worn, and injured, and inultitudes die on their long journeys, sometimes 1,000 miles or more from the seil. 'The salmon,' said Dr. Tarletun II. Bean, "wonld have been better off, it apuears, hanl it never been born in fresh water, where its dangcrs are cumulative and deadly.' In the sen it is plump, silvery, and free from disease, the arcas open to its wanderings are illimitable, it has aluundant room to flee from its enemies, and man has sought in vain to nct or enpture the fish in the open orean. Yet so mentrollable is the migratory tendeney, hereditarily implanted, that it must perforce move shorewards, seek the mouth of its chosen river, having gained which it ceases to feed, deteriorates, hecomes diseased and quarrelsome, and even dies under the hursh conditions of its sojourn in fresh water.

NUMBERS OF S.LMOM DIE.

In all salmon rivers a proportion of parent fish dic from wounds or cxhaustion-in some Scottisl rivers a considerable number do so; but the opinion has been expressed that in British Columbia, and Pacific salmon rivers generally, no adult salmon survive the migration from the sea; a statement which is without doubt, cxtreme. There is proof that not all die, and the late Dominion Fishcries Inspector, Thomas Mowat, stated his view (in 1892) that about 25 per eent of the British Columbia salmon runs return to the sea, and the statement is doubtless not far removed from the fact.

\section{LAND-LOCKED VARIETIES OF SEA FISH.}

The salmon is cav sites, now far removea

: : sea-fish, like the shad and gaspereau, and its spawning lise sea, wcre once part of the ocean; but havc, as stated, been cut off. To reach these ancestral spawning grounds the salmon must migrate; lut its return to the sea is not absolutely essential. There are indeed, land-locked salmon. In Scandinavia, Russia, United States, and Qucbec and New Brunswick (in Canada) salmon are found which do not migrate to thc sea. They might do so in some cases, as in the cases of the Chamcook lakes in New Brunswick, but do not do so. The land-locked salmon of Lake St. John, Quebec, can descend to the sea, but could not return if they did so. Whether now cut off by geographical conditions or not, the hereditary instinct has been lost, just as the domesticated duck has lost its migratory instinct. Such instincts or tendencies are difficult to eradicate, and the hunting, especially the bird-catching tendency of the cat-tribe, is still strongly re- 
tained by the domestic eat in spite of its ten thousand years of association with man.* I have elsewhere dealt with the possible modes in which land-locked varieties of sea. fish may have originated. Hence the occurrence of smelt in Loch Lomond, New Bruns. wick, can be understood, or even their occurrence in lakes in the Gatineau region, far removerl from the sen (60) or 700 miles). Huke (Merluccius) are kmown to take to a fresh-water life, and one Gadoid, the Burbot or fresh-water Ling (Lota) is purels a fresh-water species, and occurs in the most remote lakes of northwest Canada, as well as the great lakes and counected waters. 'Fishes are not so sensitive to changes of temperature, to change in salinity, or to other phenomena, as supposed; neither do they dread currents.' Professor McIutosh recently pointerl out, 'tlic sulnun, the sturgeon, and the eel are at home both in the sea and fresh water, and the flounder, the mullet, the sea-perch, the sprat, and the sparling, take little notice of varying salinities. The Baltic herring can readily be acclimatized to fresh water, even to the extent of leing killel. if by aecident it suldenly falls into sea water.'

IIEREDITY IS TIE CAUSE

The migratory instinct is an old, hereditary and deeply implanted tendency, and the surprise is, not that it is retail.ed so strongly $i$ the sulunou and similur fisls; but that it is ever lost. Just as the migration of birds cannot be fully or satisfactorily explained on grounds of utility, or of intelligent observation and ratiocination, yet is so wonderful that a pair of swallows will leare their nest, migrate across France and the Mediterranean to Algiers, and in the following spring will return, not only to the British islands, or the same parts of those islands; but to the very barn or house. where their old nest is still to be found. The 'homing' powers of pigrons and of eats. inderd all the phenomena of animal migration are to be traced to lieredity, and in the case of fishes, can be cxplained as set forth in this report.

SOME FISIIES POSSIBLY XON-MIGRATORY.

There are some fishes which do not, so far as our present knowledge goes, show this pre-determined and fixed cliaracter. Such issles appear to be neither true to an established route of migration, nor confined in their wovements within local and limited bounds. The sharks and dog-fishes in the sea are erratie and unecrtain, they resemble the wolves, which may infest a district for a time, destroy the deer, and then more to other regions. Hordes of dog-fish, and schools of sharks, seein to liave the same erratic bunting instinct. In fresh-water the carp, introduced into Canada twenty or thirty years ago, and the native eat-fishes, appear to huve no settled migrations, or fixed geographical bounds. Like tive house-sparrow (Passe iomesticus) they wander everywhere, and make themselves at home everywherc. ? n accurate studies may show that even the carp has loeal and regular migrato: ,vements. We know that the whale tribe. long regarded as the wandering monster the deep, lave habitual courses, and move with great regularity along 'bents' which the whalers discover without difficulty. The eel is one of the few catadromous fishes known. It descends to salt water to spawn, thongh in remote inland waters as in Canada, it may, like the abundant fresh-water gadoid, the burbot or river ling, spawn in fresh water. That remains to be discovered; but the eel, it must be remarked, is a lighly specialized and much modified fish, and its habits afford no light upon the generil laws of fish migration.

\footnotetext{
- Cats are found in the tombe of their owners in Fagpt ombalmed, indeed mumm cats are of common occurrence dating bach 10.000 or 12,000 years at least.

$8306-3$
} 
SU MMARY.

The importance of the facts dealt with have a direct and vital bearing on fishery legislation, and the difficult problems of appropriate and effective fishery regulations. If valuable food fishes are reotricted and local in their habitat and in their movemento; if they are controlled by rigid hereditary instincts, that fact will dictate in many ways, the kind of protective measures which will best preserve the fish. The points may be briefly stated as follows:-

1. Young fish in their first stages have vertical and, later, $n$ horizontal distributory migration.

2. Maturing and adult fish move from deep into shallow water, and do not wander widely, while anadromous opecies are true to their routes, return to their own rivers, and even return to rarticular tributaries or spawning sites.

3. Fish schools also migrate when not seeking spawning grounds and probably not in search of food. gration.

4. Heredity affords the best explanation of the remarkable phenomena of fish mi-

6. The existence of local varietice (salmon, herring, \&c.) proves that these typical migratory fish do not traverse vast distances, or scatter fortuitously.

6. Few fish are erratic, and such form notable exceptions to the general rule, that migrations are regular, geographically restricted, and under the potent stimulus of heredity. 


\section{II \\ UNUTILIZED FISHERY PRODUCTS IN CANADA.}

\section{By Professor E, E. Prisce, Commissioner of Fisheries for Canada, Ottawa.}

The utilization of waste products is one of the most remarkable features of the manufacturing world to-day. The fisheries have been an exception, almost the sole exceptiou anoug the great industries of the world, and litile has been done to turn to account the waste materials and by-products yielded by the fish business. The tesh or nuscular tissues of fish and in a few instances the liver, are almost the only portions that are, speaking in general terms, made of commercial value. The liead, tins, tail, skin, bones or skeleton, entrails, and various internal parts are usually throwu "way and wasted. The amount of offal or 'gurry' and other waste unateriuls produced at great centres of the fishing industries is astounding. But apart from these by-products, which are unutilized, though the waste is fully recognized, there are also vast quantitiea of materials of value going to wrste and unutilized because no one recognizes their value, and fow renlize that they exist.

It is true that at intervals some venturesome authority announces to the world that sources of wealth are being ignored, and many cases might be instanced of schemes of utilization which are absurd and impossible. The public and governments have been repeatedly led astray through the mistakes or the ignorance of persons, not possessed of adequate practical and scientific knowledge to see the impracticable nature of their schemes. To the ordiuary observer, indeed, they uray appear fensible, and commendable.

A scheme which aroused much attention n few scars ngo mefered to the utilizaltion of lake herring. It was thought by persons not properly informed that a cured or pickled herring industry might be created on the Great lakes of Canada, and just as Scottish cured herring were in demand, at very remunerative prices in Uniter States marlets, so Ontario cured herring could be similarly supplied to these markets. The fatal objection, of course is this, that there are no herring in the Great lakes, which can be cured by the Scottish method. The so-called lake herring are not herring at all. They do not belong to the Clupeidre or herring family; but are rcally 'lesser whitefish' and belong to the salmon and trout family, which are utterly unfitted for curing in the way suggested. The bones are too few in these lesser whitefish to make a compact salt-cured fish, the flesh is flanky and unsuitable, the flavcur is inappropriate, and barrels of such fish shipped to the markets would entail loss upon the shippers. The whole scheme was Quixotic and impracticable.

Every one knows the wonderful story of the utilization of coal-tar products. These rere formerly regarded as waste nnd valueless; but the ingenuity of the late Professor Crace Calcert, of Manchester. Fuglaml. showed thint valuable dre-matters (aniline dyes) could be extracted from the gas-tar. Later, odours or scents, and the most delicate and exquisite flavours, those used especially in confections and sweet-meats, were extracter. Iater still. glycerine. vaseline, and numernus oleaginnus products were obtained until the waste by-product, the valueless coal-tar has become one of the most valuable materials in modem industriol enterprise. Other cases might be instancer: hut it is in the field of fisheries especially that products of great value exist which hnve not yet been turned to account.

That in important fishing centres where wealth. intelligence, and enterprise abound. there should continue, year after rear, the most extensive waste of materials

S.3nf -31 
coitaining prod"cts of importance and value is truly astonishing. The 6sheries, indeed, offer a promising arena for investigation in this regard, and this report is intended to direct attention to some of the unutilized materials which are available for utilization in Canada.

IIOW PRODUCTS ARE WASTED.

There are three principal ways in which fishery resources of value are going to waste or rather are not being utilized so as to bring adequate returns. First there are products which are being thrown away and got rid of as useless which are of value if properly handled; second. there are products which are being so badly utilized as to bring the smallest returns possible; third, there are products which are not neglected and not recognized as included in our fishery resources at all. There is of course danger in the attempt to place on the market a new product and human ingenuity may devise methods of turning out fish for food which are reprehensible.

\section{REPREILSSIBLE METHODS OF UTILIZSTION.}

'Thus it is well known that for many years past quantitics of so-called smoker whitefish and smoked salmon sold in Chicago were not smoked fish, and had never undergulle that wholesome method of preservation. These whitefish, probably deteriorated by being kept too long, werc chemically treated and coloured by means of aniline dyes so as to resemble in colour the smoked whitefish which is so much in demand. Salmon, too, had been treated in the same way, and the method not only resulted in fish rescmbling the smoked product in colour, but thcre was no loss in weight, as there always is during the genuine smoking or semi-cooking process. In January last year the officials on one occasion seized five tons of salmon in Chicago, which had undergoule no process of smoking whatever, set in colowr and to some extent in odour they wers a good imitation of smoked salmon. A well known United States journal thus referred to the seizure of a quantity of these fish: 'Assistant City Chemist Francis J. Seiter has been analyzing the seizures, and he says that the fish are not only coloured to give them a nice appearance but that it is done secause smoking fish reduces the weight while dye adds to $i t$, therefore making a greater profit for the dealer, and a corresponding loss for the consumer. "One hundred pounds of fish which is treated by being smoked will weigh but sixty pounds, after the process has been gone through with." said the assistant city chemist. "If the fish is dytd the loss will be but a few pounds. All of the fluid in the fish is preserved and therefore a big loss in weight is saved. The manufacturcrs of aniline dye guarantee that 100 pounds of fish treated with dye will not luse niore than 20 pounds to the hundred. The loss in weight is always much less
than this."

A good deal has been said, during the last year or two, about the canning of dyed cary and other artificially coloured fish, and their sale in the markets as Pacific salmon. The best markets, such as the London market, to which Canadian canned salmon has always been mainly shipped, cannot be deceived, and will not buy or landle these false products. Where, however, there is an overwhelming population usually on the verge of extreme poverty, there is a sale of such goods; but the good repute of Canadian fish will not permit of the encouragement of thesc nefarious nethods. Our fish packers and dealers must, in their own interest, put only the best food products on the market and thus maintain the reputation and ensurc the demand for Canadian fish. Six or sevell years ago there was an outcry against certain shipments of fish from Portern Canadian ports, to Porto Rico, and therc was actually a protest issued by the Porto Rican Board of Health in 1901 against such fish. 'On many occasions large quantities of cod-fish have been eondemned as unfit for use. All the samples,' the board stated, "were poor in quality and much of it of such low grade that it could not be sold at any price.' The resident British consul forwarded the representations, nnd 
while it must be admitted that there has been carelessness in cleaning and curiug many catches of cod and otber fish in the Maritime provinces, it is also true that no cured codfioh in the world can compare with the Canadian catch on the whole. It certainly inferior to theim. part of United Statea trouble in Porto Rico, it waa hinted, arose from a deaire on the feld open to htatea ahippers to bring Canadian fish into disfavour, and leave the canned lobsters, which alone. A similar prejudice was created in Europe regarding lobster impresere graded as of high quality. Parisian and London buyers were frequently United Stat this claim of United States superiority, whercas almost the whole of the packed here, and shipued to Europers are Canadian lobsters, eaught in Caunda, and men and agents.

\section{BEST PRUDLCTS ESSENTIAL.}

While the above is truc, it remains no less imperative that those, who put up and handle fish products in Canada, must maintain a high standard and thus secure, as was the case for many years with Britislı Columbian cauned salmon, a better price than that paid for United States and other canned salmon. Fifteen years ago I perscinally called the attention of prominent curers and merchants in IIalifax, N.S., to the absolute necessity of avoiding carelessness in gutting and cleaning fish, and in preventing their unduc exposure to the sun, when on the vessels and wharfs. I so reported to the Minister of Marine and Fisheries at the timc, and havo ny report now before me; but one curer to whom I objected that there was too much 'blood' re. maining below the backbone, near the shoulders, gave me the reply that the "negroes of the West Indies preferred strong smelling fish.' The so-called blood is really the decayed kidncys, dark red organs, which are nost offeusive when they become putrid. The quality then of our present fisl proluets must be maintained and improved
wherever posible.

\section{KNOWN NEGLECTED RESOURCES,}

Before referring to industries that can be created by utilizing products not rocognized ns food products at all by fisheruen, I mny, in passing, refer to the long neglect of tisheries, of which our people were well aware; but to which they were indifferent. Thus elams which ubounded on our Atlantic shores, and eels which water to countless millions uy our enstern rivers from the sea and grew in fresl coast the neerlect more extraordinary. When delivering an address in the negleeted these newspaper from which I culled the followingsized in ertain artieles in a Vnneourer

\section{Fish Other than salmun.}

' Two promising developinents hare markel the fishing industry. One was that the export of fresh fish has been established und with $n$ suceess that indicates pernianency. 'The other is that sudden attention lins been bestowed in the curing of fish and the prospret of securing a market lins presented itself. To write a chapter on the fish of British Columbia which would do justice to the subject, would make it senting Hamlct with of this article, lut to omit nll reference to it would hre pre-

Bricfs, withont giving left ont. const waters are: S 
trout (Salmon purpuratus) which some authorities alleged to be the true salmon and not our salmon of coinmerce; cod, of which there are several varietien, excluaive of the whiting and 'skil' which belong to the Gadus family; balibut, or cinnt cole, very abundant in nortbern water and of ereat size and fine quality; berring, amolts, ardines, cen bass, floundern, soles (wronsly so caliod locally), and oulachons. All these are fials of commercial value. A fow otbers, such as Tounmy cods, crey luges ancl eapelin, are offered very rarely. The frenh waters inlaud contain in great abundance trout, eturseon, land-locked ealmon and species of whitefish. The sturgeon srows to an enormous size, sometimes caught woighing 1,000 lbe. The cod banks of British Columbia have ovidently not beeu definitely located as yet, for while the youn como into the baye and inlets in laree quantities, tho pareut fish is not caught in sufficient numbers to warrant tho belief that his peculiar labitat has been discovered, though it has been fuirly well in Mlaskan watere.

For four or fivo years back there has been n conviction in the minds of many that the export of fresh fish to the large centres would pay, and that it would ulti. inntely ass'ime large proportions, but nuinerous ventures and experiments were made without sucess, and it seemed as though British Columbia was too far from the fresh saimon and halibut were importance. However, last year several carloads of with any great financial suecesent to New York, and while the venture did not meet and this year they have sarther attempte in the samo line of several companies engaged in it up somewhat energetically. It is the intention shipments of fresh engaged in it to continue shipments throughout the year. Trial and England, regular shipments

'Thero need countries, which have practically in disposing of fish products, for there are many could be sent if once a sanadian shipments Four or five yeare a systematic scheme were decided upon and properly launched. sioner in Centro and been Canadinn Trade Commisfact that "while Cunado, with South 4 crichad with its rich and raried fisheries had practieally no fish trade producing country. A prominent Toronto jourge quantities of fish, in various forms, to South America.' which appenr mainly to be in a leading nrticle, attempted to deal with the rensons. regarding mainly to be indifference and lnck of enterprise. though it remarked the worle'. sold comparatircly nothing, probably the greatest fish raising country in quite likely that the late way of fish to those countries. It is ditions so far as Canads of means of converance has something to do with the con-

llappils there hada is coneerned which Mr. Sheppard noints out.' nffres a great fiell for fish business.

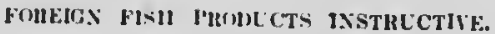

Nations like the Norwegians and Japanese have always utilized a vast number of tisll prorlnets which we igiore. The fact that Canadian waters have produced in u11paralleled abundance the most superior kinds of fish, salmon-trout, whitefish, pike, perch, sturgeon, dec, in the inland lakes and rivers, and cod, mackerel, haddock, smelt, herring, lobsters, oysters, \&c., in our seas, amply accounts for our indifferene? to other fish products which are viewed as inferior. In Mediterranean countries, Italy, Sprain, Greece, \&c., the fish markets shound in edible marine products, which no Canalicul ever thinks of cating. The Chinese. Japanese, and our native Indinn trilues regard ns luxuries many fish and other produce of the waters. which we view as bruiratl contempt. Just as the Scotch reject shrimps, prawns and cels from their list of 1nille delicacies, while the English regnrd them as dnintiss. so the Franh 
entren the craycinh and certain mollusks, which are not on the Briton's usual bill of pare. A flalifax correapondent, two or three yeara ago, gave the details ln a local

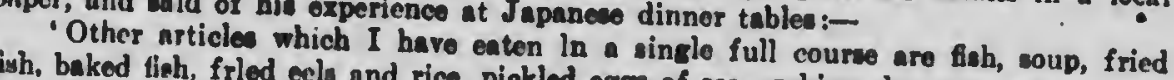
fish, baked tish, frled ecls and rice, pickled eggs of sea urchins, dry octopus or squid, boiled abulone, sea weed jelly and shrerlderl whalo enrtilage piekled.'

\section{-}

I lavre in a previous report dealt very fully with the carp question," but as chnirmulı of a secial fisherie commiesion, which has been taking evidence, during prensod with the along the waters of western Ontario, I have beon once more intishermen the carp are in demand the matter with leas alarm for, at certain times of the year epecially as the fish ind in United States markets, and bring remunerative prices, but carp will never be ane in numbers very fant and grow rapidly to a largo size; appetising form. The fopular article of diet in Crnada unles put up in nounc inhermen themselves, who capture carp, confess that they or dore. When they much prefer good whitefieh, lake herring and pickerel teupting uppearaucu mozed the German carp acquires a dainty farour, and a a little enterpries by It appeare that new industry could be created with cleaned, liced into bending theso fish into the market. The carp aro split open, hours. The brine should not strips and soaked in salt and water for abuut twelve judge of the right quantity. house or strips ar. then placed in a smokecorn cobe or other acreeable, laid out on a frame over is fire. Maple chips, and by placing the for the for the heat and the frame on which the spread 18 th 14 inches from the fire, be taken that the partly cooks and smokes the fish at the same time. Care must some sample ship do not acquire a disagreeable black colour, as in the case of some sample shipments of smoked carp sent to the Buffalo markets the black colour of objected to. If the fish are properly smoked there is no objection to the adoption give them artificial yellowish brown dye or, stain such as burnt-sugar fluid, which will of the fineat of appetising colour. Smoked sturgeon is regarded by epicures as one Ontario or experienced carp would bring a prepnred. There is no doubt that smoker during a part of the year is very low.

\section{IMPROVED MEANS OF UTILIZATION URGENT.}

There are many fish, which by a slight process of curing can be made to yield far larger returns than when sold fresh. Had Scotland shipped all herring in a fresh or slightly salted (semi-cured) condition to Germany, Russia, or other countries, to be there converted into other food products, there would never have been buil up the fishing industries ing industry of to-day-one of the most profitable and important tion, vast quantities of half- On the Atlantic coast, Canada ships, in a fresh condicanneries in the State of $M$ aine. The fish becn manu State of Maine. The value in 1905 was nearly 8700,000 ; but had these times as much.t 
value in 1004 being $\$ 2,000$ (for a pack of 604,200 caun); but in the future this induatry. involving the emplorment of a larme amount of labour, the buildine of machinery, making of cans, fe, will no doubt develop on our own shores just as the lobster canaeries bare grown on the ssme eastern shores to be a rust industry.

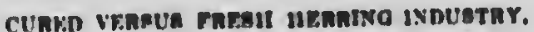

I nimilar loses of busiuma han continued for unnyyurars on tho Pacifie coant." Britioh Columbia firms have exported in a fresh or wemi-freoh (slighth salted) con. dition. immense quantities of fine herring to the State of Washington to be utilized there either in kippering or an bait or as fertilizer.

This oxport of berring as raw material bringm the poorest retums, and the province of British Columbia would receive one hundredfold returns were these herring cured, or kippered, or canned in the Dominion, or enld ns bait direct to the fiahing boats at Canadian ports. As United Stntes citizens have been mainly active in oncouraging in Britiah (olumbin, nucl onrrying on under the numpion of Britisls Columbin firm this herring export, the greater interests of the provinee were not, of course, recosnized; but the limitation of this inferior and less remunerative traffio is the main mean for cultirating a profitable and important British Columbia industry comparable to that of Scotland. Tho Scottish berring ouring experinent, carried out at Nannimo by the Dominion gorernment, in accordance with my recommendation, has proved that British Columbia herring can be converted into a cured product not leas valuablo than the esteemed Seottioh herring. Several important British Columbia firms have already built shers and wharfs, and commenced Scottish herring euring operations, with the poswibility of lnewe developments in the future.

A Victoria newspaper in 1906 emphasized this great possibility, and called nttention to the growth of a canned herring industry on the Fraser river, the supplies of fresh fish being obtained at Nanaimo:-

- The Windsor cannery of New Westminster is taking daily consignments of several tons to the Royal City, where they are being eanned and shipped to the eastern market. So great are the orders for fish besieging local establishments that it has been found necmesary to put on a night shift, and while a very large force is working in there establishments there is a standing advertisement in the local papers for asuistnats in preparing the fish for market. Judging from the present outlook, the fishing induatry here promises to develop in importance subordinate only to mines.

Yet while this utilization in Canada of fish caught in Canadian waters was thus hoing energetically started and developed, a serious leakage was at the same time going ol. ou an extensive scale, viz., the shipping of rast quantities of fresh herring. or very slightly, but not really cured fish, to Seattle and Tacoma, to buill up n rival euring industry just across the line, thus competing with our infant industry, with a view to its dostruction. I quote again from the same journal:-

- The herring industry in Nanaino is now in full swing. The fish are rumning in $n$ coustaut stream as never before witnessed this season nud the curing estnblishnents are working 24 hours a day with a large staff filling orders that have been on file for months back. There are now no less than three steamers making semi-weekly trips to sicutllo and Trmom with fresll herring. The Ranger, McCullough inil Squid are the versels muployed, each of which carry frnm scventy to a hundred tons a irip. Cuptain Fultiol of the steamer $\mathrm{M} c \mathrm{Culloch}$, which cleared yesterday for Senttle, loucded to the water line, says that an enormous market for local coneumption is being built up in senttle. Sow that Seattle people are being introduced to the delicney of Nanaimo herring. the denand is growing steadily. From other parts of the state of Washington

- Ilie lite A. R. Milne, C.M.U., custome rollector, Victoria, B.C., said in 1895: Phere is not a systematic betring fishery in the wholn l'aritis mant, yet the sambich islands want them: 
orden are aloo comi.ug In for Nanalmo fish, so that this avenue of the herring luluatry ls provine a protitable one for thoee engserd In li. Just now, Seattle dealers are placeIne Nanalmo falh In cold etorage so as to be In a poultion to handle outelde orders.'

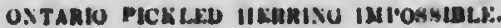

As ull experts ure aware, there are limitations to the curing and cannimk of bah. All Goli cannot bo satisfactorily eured or cauned, and many ulstaken project have been urged by perwons laeking in knowludge wid experience. Thus, the melieno wet forth in Ontario four or flve yenrs ago tlint a Scottish herriug induntry sould be created on the great laken wan most absurd, for two reasons:- (1) Tho so-ealled lake herring are really leseer whitefish, and will uot stankl euring lin the way tho herring will, with It very uumerous bour holding the tlewh well together. (2) The trade would rofuer in accept aw herrine an unouitable pickled fish such as the sual! speien of whiretish, miscalled by all the tishermen, lake-lierring. For the same reasun, viz.: the nuture of the fleah and bones, the sunclt cumnot be sutisfaetorily parked in tins. The smelt, like the so-ealled lake herriug and the whitefish are snlinonoids, and have nore of the nature of the salmon and trout than the herring or sardine, hence experiments tried in New Brunswiek were not satiofactory. On oprening a pau of smelts the ment was fousd to have fallen from the bones and had " dry 'jumbled' appearance and fur lese appetising thou the compaet neat-looking wrrliues, though the flavour was excellent. The delipious eaudle-fish or oulaehou of the Paeifie coast, like the smelt, is not sultable for canning, though the United Einpire Salmon $\mathrm{Cm}$, $n$,y, with ample eapital proposed to experiment in the northern

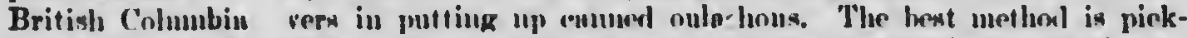
ling and preserviı. in kegs, though if nicsly put ip in lonk unrruw buttlen in vinegar or other preserving fluid, ther might in a sumeen In the markets. As the flagh adheres loosely to the backbone it falls off in 'ehunka' when rookerl and ennned.

\section{TUNNY INDUSTRY IMPOSSLLE.}

No one accuuinted with the great 'Tunuy fishery of the Meliterranean, or familiar with the tlech of that fine fish when placed on the table, eau doubt that, if the large specimens of the Tunny (Thynnus thynnus) paught every season on our Atlantic coast could be preserved and nanketed, $a$ denand would spring up for it. Its importance in France is next to the sardine, as M. Pierre Lemy, a preserved food merchant in Paris said, 'Après la sardine le thon (tunny) est, en France, le poisson qui est-l'objet de la fabriention la plus importante daus le renre d'industrie dont nous nous oceupons iej. In majeure partie du tho: péché dans le golfe de Gascogne est

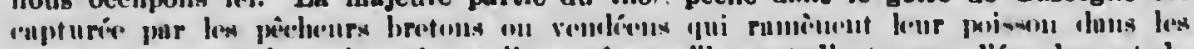
ports où existent des uxines de sardines, sîrs qu'ils sont d'? tronver l'écoulement de leur butin. Is plupart des usines de sardines fabriquent, ell effet, du thon conaervé, - Paris Fxhib., 1000, Memoires, Congrès Internntional d'Aprieulture et de Pèche, p. 35.8).

The mode of putting up the flesh of the tunny may be lorinfly stated:-The fresh fish deprived of the liead, tail, fins, and entrails, is cut into largo pimese and boiled in salt and wrater. After thus being enoked, the piecs are dried in ehambers through whieh pases a stroug eurrent of air through numerous openings. The dried porti ns are ent down to appropriate sixes, placed in eans, covered with olive cil. sealed rometipally. and hoiles in retorts like sardines. The tunne tring allied to the maek el. has a good flavour and is in high favour where its qualities are reengnizerl. Thes are called mapkerel sharks in mistake, also horse-markerrl, in Canada, and exerpting that the Gaspé residents have iren accustorund in salt a few in barrele at times they have hann "weivally thrown away and wasterl when eaptured hy the fishermen. I have 
seen them rotting on the beach at Yarmouth, N.S., and in Gaspé basin, P.Q. Smoked tunny, and bonito, really a smaller species of tunny, are popular in Japan. As Sir Frederick Nicholson says, it is an excellent product, 'econonical in use, andwill keep good for years.' The same authority informs us that the fish after being opened and boned is cut into longitudinal strips, boiled or steamed, dried on trays in the open air and then smoked orcr a slow-combustion furnace whicls burns various woods and sawdust. $\Lambda$ dozen or more trays are piled up so that the smoke penetrates the various tiers, and colours them a dark brown, after which the fish is given a final drying in the open air or in a dricr at $70^{\circ}$ to $90^{\circ} \mathrm{F}$.

\section{SKATE, SHARK, DOG-FISII, SHARK'S FINS, \&C.}

Skatc, sharks and dog-fish are abundant, too abundant, the fishermen think, in Canadian seas; but they have been little utilized. I dealt fully with certain phases of this matter in my former report on "The Dog-fish Pest in Canada," and since then the Dominion Government have attcmpted in thrce different localities. Shippigan, N.B.; Canso, N.S., and Mud island, N.S., to utilize these fish, particularly dog-fish for fertilizer and oil. In my report I referred to the edible qualities of the dog-fish family, and on recent visits to Boston I found in that fastidious city that some prominent tish-dcalcrs' stores cxhibited choice cuts of a firm white tish labelled 'ocean whitefish,' which was no other than the dog-fish (Acanthias) of our waters. It was regurded as very good by those customers who had tried it. The central part of what is called the 'wings,' i.e., thic large breast tins of the skate are regarded ezen in England as a delicacy by epicures, and skates' 'wings' find ready sale. The Chinese have always hcld sharks' fins, \&c., in esteem. In the Norsk Fiskeritidende, February, 190i, I] .50 .55 , is a short article on these dried tius and the Chinese aud Japanese markets, witl an illustration on page 51 , showing how the fins require to be neatly cut off at the base and hung, after being salted, to dry. Of eight species of sharks and dogfishes generally utilized, four at least occur, or almost identical species occur, in Canada, viz.: ('archarias, Alopecias, Lamna, and Mustelus. 'The dried fins are sold by the picul (1331 lbs.) i.c., about $16 \frac{1}{2}$ piculs to the English or 'long' ton. The price varies according to quality, but may be as much as 50 cents per pound ( $\$ 70$ to $\$ 80$ per picul). They are largely handled by Messrs. Aagaard, Thoresen and Co., Hong long, British China, and there is no limit to the market. India, especially the Madras Presidency has largely exported shark's fins to China. Shark and dog-fish paste is also a commodity in demand, especially in Japan. The flesh removed from the boxes is pounded into a paste, a littlc salt being added, and it is made into rolls, like rolls of butter, which are steamed for nearly half an hour. These rolls of a lardlike appearance will keep for several days, even in hot weather, and it is in general use. The flesh of sharks and dog-fish has long been a staple article of liet in New Zealand and the Southern Pacific islands, and if these fish, captured in Canadian waters. could be supplied to these natives, a ennsiderable demand could be created. The Maoris enpture the fisl by means of haited hooks.

Fresh mullet is the one hait $\mathrm{n}$ shark finds irresistible and will always bite at, but where this is not to be had a very good substitute, and a bait sharks take is the large six-ineh musel, which is to be found in numbers on the submerged sand-banks of the enast.

Great quantitics of these shell-fish are eollected in readiness ere the senson eommenees, and heing placed in heaps on the beach.

But before commeneing fishing operations a large loosely woven flax receptacle. containing the polt and offal of some slaughtered animal, a bullock or a sheep is hung 1903.

- The Dog-fisb Pest in Canala.' Special Report, Mar. and Fish. Report (Fisheries), 
over the boat, the blood and savour of it filtering through render the sharks perfectly ravenous. Dozens of them flock around the floating bag, making ineffectual snaps at it as the man holding the line jerks the tempting unorsel from their jaws. In the clear water every motion of th - fish can be watched, and their rushes at the bag avoided.

The baited hooks are suspended near the bag and considerable catches are madc, especially of which are called ground sharks.

Blue-shark, shovel-nose, and haminer-heads are all caught in numbers by the uatives, and all are found equally good eating.

None of these species, however, attain a size of orer twelve or fourteen feet in length; indeed, the average run of size is from six to eight feet. The flesh of the larger fish is said to be too coarse and strong-flavoured, and the fishermen accordingly discard anything over ten fect long.

The carcasses after being cleaned, are hung in the sun to dry upon transverso poles supported hy uprights 20 feet high, and in tliree or four weeks they are cured. and dry as wood. They are then packed in flax mats and transported in bales to the various native villages. Dried shark has ranked ligh as an article of fond amnngst these Pacific natives. The smaller sharks or dog-fishcs and their allies, the skates and rays, are, however, better adapted for table use in civilized countries. heing superior in texture, colour and flarour, and if properly clsaned. the cntrails and skin cnrefully removed, and the flesh prepared in small 'chunks,' there is no reason why it should not become a general fish food, like the once despised flounders and flatfishes, the sea cats and frog-fishes, which now readily find sale in the best Furopenn fish markcts.

\section{ROE OF FISHES.}

The eggs or roe of fishes is chemically a nutritious material and caviare, or the prepared roe of the sturgeon is one of the most esteemed and expensive of fish products. The public indeed have made such a demand, especially in the United States, for certain fish containing well dereloped roes, that the price of fish like roe shad, in Fulton Market, New York, last season, sold at 35 cents each, while shad not containing roe brought 15 cents. At Boston and New York restaurants the cooked roe of a shad costs 75 cents to the retail customer. But roes of fish other than sturgeon or shad have a value as food, though so generally wasted and thrown away with the entrails, as gurry on the great lakes, splendid caviare has been made of the roes of suckers, pickerel or dore, and other fish, by enterprising fish merchants. Such caviare if coloured with some harmless dye should rapidiy become a recognized and profitable commodity. The most important demand, in many respects, for fish roes is, however, for use as a lure or bait for attracting and collecting the wandering sardine schools. Just as 'pummy' proved effective in the mackerel fishery off the Atlantic shores, so preserved 'roe' or 'rogue' is valuable in the sardine netting operations. Norway has a most remunerative 'rogue' industry, and Newfoundland has provided a good deal though on account of poor packing it is sought less eagerly than the Norse cod rocs. The United States also produces this article. The well-dercloped eggs of the cod, haddock, mackercl, hake, pollock, \&c., are best for the purpose. The roes are carefully removed entire, salted and packed tightly in barrels. They are repacked later in barrels through which holes have been bored one-quarter inch in diametcr. The brine cscapes through the holes and the roe is preserved in a dry condition. Dr. Hugh M. Smith, in a most interesting report (United States Fishery Bureau Bull., 1901), gave the details of the industry, and points out that the eggs must be separable, that is, well formed, the salting must be carried out while the egg mass is fresh, being placed in layers of dry, rather fine, salt, and after the first packing, should be repacked, graded according to quality or state of ripeness, and finally packed in barrels holding $308 \mathrm{t}$. 316 pounds weight. Loose eggs or broken roes must be packed separately. 
There hare been spasmodic attempts to supply the demand for 'rogue' or cod's roes cured in a way suirable for the European eardine fishery, and amongst many references in official reports, I quote the following from a Dominion fishery officer's report about twenty years ago, in which reference is made to the preparation of cods roes on the Gaspe coast:-

' Cod is a delicious fish, and one in which there is no loss. It supplies human food, oil and a kind of glue which is as much prized as that of a sturgeon. Iargo profits are a lso realized from the sale of cod roes. The preparation of this article, which yields a large revenue to Newfoundland fishermen, was until lately comparatively unknown to our people; but I notice with pleasure that more attention has been paid to this branch of industry than usual. Four or five years ago the Gaspe people began the preparation of cod roes for export, but, for reasons unknown, the trade was dropped, IInving plenty of time on hand this season, they again set to work, and the statistics show that on the coast of Gaspe no less than 622 barrels of cod roes were prepared, giving a revenue of over $\$ 4,000$. Newfoundlanders export this article to Norway and Frnnce, where it is used as bait for sardine fishing, and sells from $\$ 5$ to $\$ 8$ a barrel.

' Codfishing on our shores is divided into two seasons: summer and fall fishing. Formerly, the only fish that were dried and went to the merchants were those caught after August 15. The fish caught after that date were salted and sent to Montreal or Quebec in barrels, or were traded for ihe purchase of winter provisions. But now that almost everywhere in Gaspé, and especinlly in the western part, the system of engagcinents is changed, there is so to spcak but one season fishing, the summer fishery; since all the fish caught is dried for export.

"Although cod is met with on the whole coast of Gaspé, thcre are several places where it is found in greater abundance than others, such for instance as Percé and the neighbourhood of Bonaventure jsland and of Cape Gaspi. In these places also the fish remains a greater length of time than at others.'

Along the Mediterranean, in Japan, Chinn and other enstern countrics, the large masses of eggs, orange coloured or reddish, which are contained in the sea-urchins or priekly sca cggs, abundant on our Atlantic and Pacific shores, are solrl in the markets as food. They are esteemcd as highly as oysters, and as sea-urchins are so rery plentiful, they might be turned to account if pickled and shipped in jars, like jant, to the countries where sea-urchin's eggs are an article of diet.

The suggestion lins been made that the eggs of dog-fishes and skates, which are obtained in great numbers when these fish are being capturned and utilized, might to made of some use. When the dog-fish are being landled at the Government Fish Reduction Works, these eggs (like the large cggs of birds removed from their shells) may cover the wharfs to a depth of several inches. They are most excellent and lutritious food. In my former report on the Dog-fish, I mentioned their use in Scandinavia in the making up of purldings, nnd recently an cminent English chemist, Dr. T. F. Thorpe, in an official report to the Cornwall County Council, emphatically strites that:-

'The eggs of the dog-fish, when loiled, are rery similar to an ordinary hard-boiled hen's cgg, and a wholesome and highly utritious fool.'

THE SEA-CL'CLMBER OR. TIEPAXO.

The tropang is an esteemerl artiele of foorl in China. It is really the dried sca-culember-a large kind of sea slug or echinoleru* -often 12 to 15 inches or more in length and 3 or 4 inclies in liameter. These ereatures abound on the Atlantic and Pacific coasts of Camnla, and may be taken with ease by nocans of a dredge; zet. so far as I am aware, this abundant fond proluet liss never been turned to any

- Often called 'beche-de-mer.' 
aecount by our people. Their preparntion is very simple, and when dried they sell in Canton for $\$ 45$ or $\$ 50$ nor ton. It would eost little to gather them, and as tiles would find a ready and lucrative sule anongst the Chinese and especially, if shipped to China, that it is surprising no tirm bas ever entered into the business.

The late Julge Swan, who notierd the abunlance of sea-eucumbers or linlotluurians on the eousts of Vancouver island and Queen Charlotte islands showed some specimens to severii Chinamen, who at once declared then to be the best quality of 'whetong,' one of ihe Chinese names for trepang. 'The trepang, when prepared for market, is an ugly looking, brown-coloured substance, very hard and rigid, and can be eaten ouly after being softened by wnter and a lengthened process of cooking, when it is reduced to a sort of thick soup by the Chinese, who are very fond of it; and when eooker by a Chinaman who understands the art, it makes un exeelleut dish.

The preparation of the trepang for market is simple. They are to be boiled in wnter, either sult or fresh, for about twenty ininutes, fuld then slit open. eleaned, and dried. Those dried in the open air or sunsline bring a higher priee than those dried over a wool fire, which latter is the usual process adopted by the Mfalays. Some varieties repuire boiling for only a few minutes, or till they become firm to the toueh. They must be dried thoronghly, as they absorb moisture rendily. and are then linbla to becomo mouldy and spoil.

Europenas who have tried trepang report that it is very good, and if the trepangs: nfter being mutted are hoiler in a drenetion of 'artemesia' it is said to be preferable. to the salt cure. They should be spreal on a hambon frame and driel in the sulu. New Calerionia, the Parifie isles. Malar, the Tuadrones and the New Hebrides supply grent quantities: but when drelging in southern Tow Brunswirk. nul in varinus regions in British Columbia, it was often diffoult to maul up the dredge nu account of the mass of writhing. slimy, sin-eneunbers gathere' 7 the bag.

ABALOSE AND OTHER MIOLI,LSKS.

The abalone, which oeeurs in the northern wnters of Vaneouver island, aud off Queen Charlotte islands, is raluable both as foor and for its beautiful pearly shell.

The massive fleshy body of the abalone or ear-hrll (Haliotis) is salterl, boiled and dried, and is in great demand in China. It is often slightly smoked, while the shell is used in the manufaeture of buttous and for ormamental purposes. $A$ inng spear may be used in fishing for it from an open hrant though the Japanese fishermen in California and in British Columbia obtain it by diving. A water glass for searching the roeky haunts of this sholl-fish is usually brught into reyuisition. Sir F. A. Nicholson nfers to a fishery on the Madras coast and states that the shells alone exported to England during the ten vears, $1800-1000$ realized nearly $\$ 13.0 \mathrm{~m}$.

Quite a number of shell-fish could he turner to commereial account in Canada. Britigh Columbia alone produeing 16 or 19 different kinds, of whieh only two or three are utilized. The razcr-clam has rome into demand in many Ameriean eities: but the demand for these shell-fish hoiled and dried is mormous in Chinn. Frtensive eultivation of these shell-fish is now carrier on in Tapan.

The pecten or seallop is an esteemed shellfish. which in Canada ha a largely gone to waste. although used to a small extent for bait. A recent writer. deseribing the seallop dredging industry of Tong Island and the methol of marketiug thein. says that in the opening of the elam shells and removal of the flesh. the ehiliren of the fishermen are mainly emploved. 'A small hov or girl will open a gallon of scallons in one hour and ten minutes, and receives from twenty-five to thirty cents per gallon, ar. cording to the size of the shell. large fish filling a measure much quicker than amall ones. An expert adult will open two gallons an hour. As it takes two bushels of seallons to vield a gallon. an enormous amount of shells has to the handled. The emptied shells arc thrown in piles outside eael house. 
The average catch for each boat is thirty-five bushels a day, but when scallops are plentiful a boatlooad has been known to result in one hundred bushels. A large per centage of those taken are seed scallops, and there is need of reform in this respect. They are better for eating after they have spawned, and as the average number of eggs laid by a seed scallop is one hundred thousand, each one destroyed, though only twenty per cent of those spawned might live, means a loss to the industry the following season.

'After being opened the scallops are thrown into water to soak until time for shipment, and here is a "trick of the trade" not generally known. Soaking scallops in water causes them to swell, and in this way a shipper can increase the bulk of his shipment nearly half. Five gallons freshly opened will increase to seven gallons by this process; and it is rumoured that they are sometimes soaked over again by retail fish dealers. This soaking process whitens them, but it takes away their sweetness and fills them with water to such an extent that frying them crisp and brown is almost an impcssibility.'

The pecten or scallop, like the cockle and the mussei, is a tough attractive bait, as iwell as an esteemed table delicacy a portion of which may be prepared like stewed ossters, or served as a soup of the richest and most appetizing character. Great bels of pectens exist, though not generally known, on both our Atlantic and Pacific coasts. They lave hitherto been practically unutilized.

\section{NEW B.IT RESOURCES.}

Cockles and mussels are of market ralue in most countries. Boiled and dried, the Chinese regard them as a delicacy, but cockles are now coming into demand in Tinited States cities and amongst Canadians. There is no more dainty or delicatc food. Vast areas on the Atlantic and Pacific shores, could be made to yield quantities of mussels, and in ricw of the great demand in Scotland for these shell-fish for bait purposes. it might be remunerative to ship them to the British islands, where they have sold for $\$ 5$ to $\$ 10$ per ton in the shell. Holland exports immense quantities to London and to Scotland, and it is a most profitable business. At St. Andrews, in New Brunswick, the extensive sand flats there are yielding remunerative catches of cockles. The St. Andrews Beacon some months ago said:-

- The cockle business is assuming quite respectable proportions in this locality. This season (1906) a number of men found lucrative employment in gathering theso shellfish from the beaches, the local price being 45 cents per bucket. The largast exporters say their shipments this season will total up over 2,400 buckets, and they have many orders that they will be unable to fill, owing to scarcity of men. The cockles are shipped direct to the haddocking fleet at various points on the New England coast. They are used entirely by the handliners. Linefish like cod and pollock are very fond of this bait, while the dogfish have no liking for it. In using it the fisherman breaks the shell off and then puunds the meat into a pulp. otherwise it will harden and choke the hook. Each fisherman is provided with a hammer and a small piece of flat irou (the latter being set in the ressel's rail) for this purpose. The demand for this kind of bait is steadily on the increase. It is worthy of remark that this is the only locality west of Portsmouth, Mass., where cockles can be found in paying quantities.'

Other bait products arn whelks, anemones and lampreys. The last-named fish abound in certuin Canadian tircrs and lakes. The Dutch fishermen have long found the lamprey cut into pieces, a most durable and successful bait, and the Thames fishermen sell about $\$ 4,000$ worth per annum to the Dutch fishermen for that purpose. They hare bouglit from the Thames fishermen $\$ 3,000$ to $\$ 4,000$ worth, while the Yorkshire fishermen, at Scarboro and Whitby find lampreys one of the best baits for turhot. New baits are often found to rastly increasc the catches in long-line, or 'trawlline' fishing. Tampreys are also said to he a gool foorl; but their use wial probobly never be general on the table. Ther might, if tried, prove mast effective in sea fish- 
ing, and possibly band-line fishing and in sturgeon fishing in freah waters. A change of bait has frequently most unexpected results. Professor McIntosh has said: 'Careful observations... have demonstrated that in their season, and by the use of anemones for bait, and then of gill-nets, cod (said to be 80 rare) can be caught in hundreds by a single boat." Again, the same authority refers to the "substitution of anemones for mussels, of cuttlc-fishes or squid for herrings, of lobworms for scallops, und of the alternation of gill-nets with tempting bait of various kinds. Few appre ciate the revelations mude by such changes of method.' +

SEA-WEELS AND MARINE VEGETATION.

'Sea-weeds,' wrote Mr. P. L. Simmonds, 'are used directly for unauure, for the manufacture of soda, iodine, bromine, and some like Irish moss for the manufacture of gelose. Dried, they are used for ornamental purposes. In many northern Eurcpean countries, sea-weed is used in winter for feeding horses, cattle and sheep, ancl it is eaten by.deer when other food is scarce. Last year United States Consul Rasnussen, of Staranger, referring to the handsome returns brought by the sen-weed harvest in southwest Norway, who calcined it and sold the ashes to British agents, nointed out the raluable chemical products yielded, including iodine, and added, this remarkable statement:-

- As a source of income, adds the consul, sea-weed has in a rery fow years aurpassed fishing and agriculture in fortune building. Old debts have been paid off, and land that was formerly unproductive has been drained and filled.'

Of course the amount of iodine is said to vary in the sea-weeds from the different consts; but whether these plants on the Canadian coasts are rich or poor in iodine can be decided only by tests. In Britain and France, where ioline manufacture is an old industry, the amount of iodine produced by a ton of kelp (kelp is the weed burnt into hard, dark coloured masses or cakes) is $10 \mathrm{lbs}$., and 20 tons of fresh wet weed makes a ton of kelp. Simmonds atated thnt 400,000 tons of sea-weed were necegsary to yield the annual production of iodine in Britain.

Mr. Rasmussen has afforded much detailed information upon the Norwegian sea-weed industry, and the following may be quoted:-

- The annual income (in Norway) from sen-weed ashes amcunts to ahnut $\$ 107,200$. but it enu be cloublel. Every fishemnan knows the differener between alga and tang. Only the former ean be used as raw material for the iodine and chloriodic industry: tang is entirely worthless. But of the different kinds of alga, it is immaterial, nr nearly so, whether one makes use of the large. strong stalks or the broad-lenved kind; when the weed is carefully handled, one can secure an exeellent product. If tang is burned with alga the value is decreased considerahly. and all sueh wares shnuld be refused. It is defrauding the purehasers. who might as well buy wond or conal ashes as those burned from tang. This has not been elear to the producers. which is anly natural when it is remembered rhat there has not hitherto been nroduced suffieient ashes to supply the demand, and the produet. therefore, has been partly bought without eriticism bv the manviacturers.

Besides being mixpi with 'tang,' the ashes are often found to he arlulterated hy sanil and stone. A.iga ashes are also of little ralue when derayed or rntten weed is used or when the Feed has been ton long exposed to rain hefore dried, or when the fire is extinguished ho salt water. The hest product is ohtained, as a rule. frnm the cult weed. but weed that is washed nshore is often verr gond. esperialle enrly in the rear-aay, in April nnd Mar.

The weed must be fresh dried and lumed on rosky gronnd. Should it rain the need must he gathered in a hean and encered. Alnng with the dry weed must he

- Srientific Work in the Sea Fisheries. Iondon 1907, I., p. 11.

+ Id. II., p. 3. 
placed some that is damp, to prevent the tire from breaking through, so that no more uir is admitted than necusary to promote the carbonization. The burning should tuke place on rocky ground, so that the ashes will not become polluted with sand and gravel,

Wo strungly rer:ommend sea-weed burning and careful handling of the produet, becuuse Norway enmont nfforl to luse any of its imlustries. Now that the Japanese have also eutered this ficld, the price of iodine in November, 1005 , fell froun

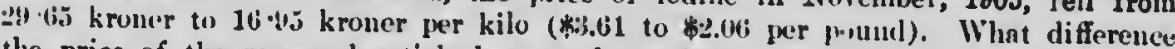
the price of the prepared article has on the maintennuee of this industry one ean understand.

The price is governed hy scveral factors. What we can do is to produce good and sufficient law material for the benefit of our maritime population and our manufacturers by eilrefiul handling of the weerl. As an example of how necessury it is and how the question of success or failure is dependent on the quality of the raw materials, it eun be mentioned that of two competing unuufucturers in this country in the production of the same mmount of coods, one used 420 tons of ashes, at a cost of $\$ 13,060$; the other used 286 tons, at a cost of $\$ 8,040$. This difference of $\$ 5,020$ in cost of manufueture represents a direct loss for Norwegian inlustry, and therewith for our nation; loss caused ly carclesmess nnd want of judgment. If the struggle for mnintaining Norwegian and Scoteh industries stund face to face with Japan-and it will coine, and come soon-the best chances for stceess lie with thr factory prollucing the inost economieally.

One of the most prolific fields for the growth of sen-weed is at Jorleren, on the southwest coast of Norway, where it uppears as veritulle furests of trees from five to six feet in h.ight, with stems as thick as ropes and as tough as leather. The weel sprouts in summer und aradually covers the ocean herl with $n$ dense brush. In the fall the rout release their suctionlike grip on the rock hottom and grent quantities float ashore. forming a sia wall nany uniles ulong the hench. The fall crop is good only for fertilizer, and is usel as such ly the natives; but in suring what drifts in is suecesinfly gatherel. tried and huruel. aud during this scason thmisands of the farmes's who own strip of the const line make thousands of bonfires, some burning as inuch as $3 . \mathrm{Mm}$ kilos a vear. This is one of the natural resources of Norway about which little was known 20 years ago. During the summer many train loads are sent In Stavanger, whence two or three enrgoes a wek are shipped to Creat Britain. Subsequent $u s e$ and treatment are to some extent seientific secrets, although the kelp ash is kunwn to be largels used in the making of indins. The fact that the industry is profitable is shown by the willingness of the English agents to pay a good prier. and

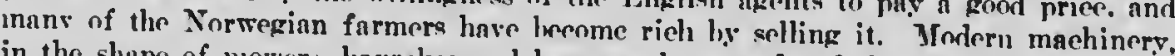
in the shape of mowrers. las.rakes aud harrows, lave replaeed the primitive farm imploments in use a few vears agn.

In orler to kmp their Glasgew. Sentland. plant fully nesupied, the Britisl Chemical Company. of Clrdehank, are encouraging the reviral of the kelp industry in the outer IIehrides. Fneouraged hy the sueress which has attended their efforts in Tiree Nortl and South Tist. Benbecula and Barra during the past three years, the compan has extended its operations to Tewis and Farris. Tearly $£ 3,000$ were distributed in the Island of Tiree alnne last season. and ennsiderahly more to kelp makers in the other islands mentioned.

The ainnunt of exertion inrolved in gathering and burning the tangles is light and the average family can earn $\mathrm{f1}$ per day. If a suffieient quantity can he obtained from the Trebrides the enmpany will not entinue to get an additional supply from
Torwar and Treland.

The common bladder wrack, Fucus resimulosus, is said to vicld more saline and earthly matters than most seaweeds, and Percira found in it nearly 20 per rent of comnoul salt. 12 per cent of potash, the same of soda of lime and nearly $25 \mathrm{ner} \mathrm{cm}$ t of sulphuric acid. A ton of reed vielding 320 pounds of ash would afford $2 \frac{1}{2}$ pounds of 
phosphates, iron and lime, $5 \frac{1}{2}$ pounds of potash, and other mineral matters, totalling

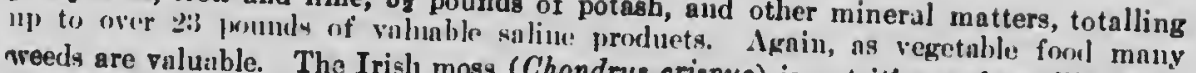
furnisles a jolly vilunble in lung eouplaints crispus) is nutritire and emollient and arate exposures to the sun and alternatise it is stored, packed in whishe, until it is yellowish white, when

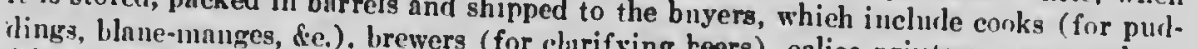
felt anc. straw hat manufncturers, (for clurifying beers), ealieo priuters, paper maknrs, large quantitics of in a semi-fresh condition is in sea moss. Dulse (Scherzmenia edinlis, Crrv.) soli]

often eaten with butter and fish, or boiled in milk with rye flour.

where it is used as a substitute forted to China from Japan anvi other eoumtries,

Ihe inhular stalkliko purtions of the fish, or as a vegetable, to thicken soups.

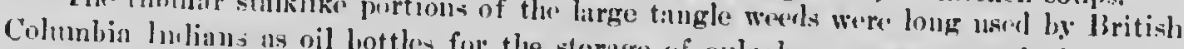
izing the hollow rounded proximal partorage of oulachon grease, a methor of util. the l'olvuresians generall proximal part of the plant which the New Zealunders and

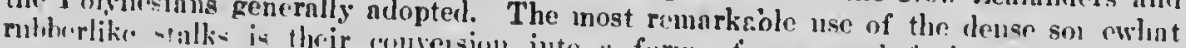

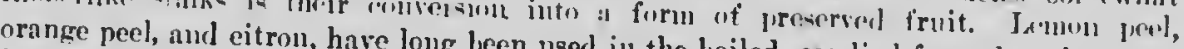
lar fleshy stalks of the huve long been used in the boiled, enndierl form, but the tubu-

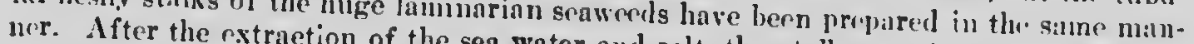
uble size, are boilel in surar aud prepurer and salt, the stalks, mit into pirees of suitfarour, texture, indeed. in all the prepared in an appetizing way so that in appearanre, aud alnost undistinguishable forsential qualities, this 'ennlied seaweerl is rqual to

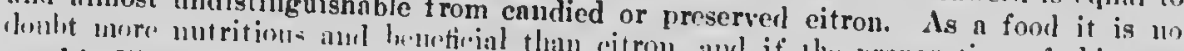
weed in Washington State, U.S. Thomsands of te is of raw for the giant tangle nay rangerial are going to waste on the Irritish (alumbia eonst that 'Upholstrrers and others there from 15 to 30 feet in length. Simmonds says thry too frequently are substituted for horse-hor stufting couches, stools. Ne., in which especially for children, because for horse-hair. They are used to stuff mattressis, them for wrapping fragile objects.' Thatie odour keeps away inseets. Pickers use (Zostern marina) used for stuffing known as crin vegetal in the former beds and ehairs in France aud Fnglnnd, being 1573, Granville. Franee rxporter nual value was orer $\$ 10,000$. On the south sherends of this dried werd. The annany years existed a similar industry, grent quantities of St. Iawrence there hils for nnche, or 'l'herbe à outarde,' nre any, grent quantities of the Zostera, or lierbe à barwhere scythes are used to eut it under ournska. Rimouski, and nlong the coast water, from bonts. Along the shore of Kinmrooted goose-grnss or bnrnacle grass marks aftei storms, nnd the long slender frundantly. It is thrown up between tide Considerable shipments are sent by reil fronds may be 5 to 12 or 15 feet in length. residents make profitable returns. along a large part of the Atlantic A similar dried weel industry could be created

\section{CORALLINES AND SO-CALLED WEeds.}

Amongst the materials east up by the sea on flat beaches, beautifil fenthrry bunches of what are ealled seaweeds are abundant. They often hare a coralline njweeds or plants at all, harler in texture than most true weeds. They are not indeed . These colonies mny be slendrr

- It is estimated that the value of this industry at Isle Verte a - _ _ $\$ 30,000$ por nnnum. (See Inspector Belliveau's Report. Isle Verte alone rangeg from $\$ 10.000$ to 
and feathery, or flat and leatlike, but they huve a crimp and nomewhat velvety feel. In the Chanuel islands and on certain small ialauds in the South of England, these co-called weeds more correctly called Hydroids or Zoophyte colonies, aro gathered for commercial purposes. On the Inle of Grain it is said that 20 to 30 tons are gathered by the local people between October and the end of March. It is in demand for trimming hats, and quite a demand has been created for it. It is cathered on the sea beach, shells and other matters removed, and after being picked over it sells for about $\$ 250$ per ton, London being the principal market. A recent writer says of this little known industry:-

"The "weed," aa it is known locally, is not cultivated in any way, but drifta anhre and is picked up upon the beach and foreshore at low tide. Exactly where it eomes from does not seem to lave leen detinitely ascertained. Some of the inhabitants are of the opinion that it grows in the deep wuters of the North Sea, and others think that its natire place is in the slablow waters of the Thames estuary. Be that ns it mas, the Island of Grain is the only part of the coast upon which it eomes ashore in narketsble qunutitins.

'Harvesting the weed provides a precarioua and uncertain employment for practieally the whole poorer cluss population of the island. Each kathers for him or herself independently, nud disposes of the result to ienlers, who in turn forward it to Joudon and foreign houses. A nurtherly gule brings nost seaweel ashore and a single gleaner has been known to piek up half a hundredweight in a morning. At other tines. when the wind is in the wrong direction, none will come in for days. The present market price of the partially dried sea-weed, from which all rubbish has been renoved, is about sixpenec pro pound. It nust be renembered, however. that the weed is extremely light and feathery. so that a pound. when dried and prepared for use, represents a considerable bulk, and, in the ordinary course, mueh labour in picking.

' Queen Alexandra, whose antipathy to the ruthless destruction of birds for the sah of their nlumage is so well known. has done much to bring sea-weed back into popular fnvour as an adornment for hat hy recently purehasing a quantity for that purpose. When skilfully blended and artistically arranged in combination with artificial flowers, the fairy sprays of this slender and charming sea-weed are capable of producing exceptionally tine effects. In fact. hats so trimmed form quite a feature of sonic of the famous West End establishments at the present time, and hid fair to become inereasingly popular in the near future. The scope of sea-weed for demrative purpoaes iq. however, hy no means confined to milliners. It can be purchased in a varicts of shades at a moderate figure from most large drapery establishments. and will be found innat useful for table and romm decorations generally. Great care must be exercised if it is to be used near enndles or other naked lights. as the dressing used to preaprve its fluffy appearance sometimes renders it highly inflammahle.'

On the Atlantic and Pacific shores of Canada these heantiful and delicate annphyte fronds are found in abundance and wonderful variety. The utilization of materials so easily gathered aud eapahle of leing turued to such ornamental and profitable acrount. must surely neellps the attention of anme enterprising pinneer.

H.F.L SKIX IXDESTRY.

Of all unlikely produets any form of leather from a skin or integume. - so thin and clastic as the skin of cels would appear the rrost improbable. Yet cor many senss, in a quiet strect near the famous Iondon Bridge. an ecl-skin factory has earriel on a paying business. There are prepared and manufactured various articles from the integument of the river fel.

The skins are manipulated by numernus complieated processes until they resemble and ronld casily he taken for leather. altbough of a more gelatinous and 
pliable uature. 'This strange comuodity is cut into long thin strips aud pleated very elosely together for whip lashes and to cover portions of the liandles of inore expeusive whips. Critain kinds of lashes and liaruesa laces are alwo made of eelskin.

The leathei is alnost indispensable in articles of this description, where tlexibility, allied with an uncoumon touglness, is desired.

\section{(11.CE, IsINGLASA, ETL.}

It is strange that with al abundance of raw materials there hns never develoned in Canada a successful tish gluc business. P'roperly carried on, with sufficient technicul kuowledge, it is a most profitable industry. Fish skins all contain more or less glue of great value. (ireat business tirms like Messrs. Marcus Ward \& Co., in Ireland, use weekly many tons of fish-glue; and the demand is cnormous. Ceinents for erockery \&c., like 'seccotine', are used in every household. Codfish skins, hake, \&c., could bo sot in illimitable yuautities, while the shurks und dog-tishes are ulso a source of

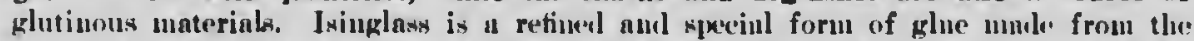
swim-bladder and certain internal menibranes, especially of sturgeon, cod, hake, sc. These muterials have beel wasted, escepting ly fur-seeing United States buycrs, who have bought dried sounds of such fisls as the st irgeon and turned them into the valu. able coinmercial product referred to-yiclding profits of not less than 10,000 per cent. Other fislı yield isiuglass, indeed last year the Canadian newspapers nnnounced that at Digby in Nova Scotia rertain United States firms were inquiring for the raw 'isinglass' material, stating that:-

'The isinglass fnctories of Gloucester, Mrass., are ordering large quantities of hake sounds from those dealers who make it their business to cure that commodity. Shipments are going forward quite freely via Yarmouth.'

The pickercl or wall-eyed pike, the river cat-fishes, the drum-fish, and certain sea-snappers yield the membrane or air-lladder from which glue and isinglass is extracted by soaking and pressure. As a recent authority rightly observes:-

'Glue manuiacture provides an outlet for the profitable use of much waste in dressing dried codfish. This material was formerly discarded as uselcss, but now tens of thousands dollars' worth of choicest glue for postage stamps. court plaster. adhesive paper, labels, enrelopes, for mechanical purposes and for sizing of straw goods and textile fabrics, and likewise office and domestic mucilage are manufactured from fish skins. The product is very much strenger and nore durable than gluc made from the skins of mammals.

'Isinglass marde from the sounds or swimming bladders of sturgenn, hake. cod. squeteague, \&c., is used for elarifying fermented liqnosa. the cellular construction forming a sort of net which carries down floating narticles.'

In Japan sea-weeds of the genera Gelidium and Glconeltis are used for glue. and for imparting lustre and stiffness to textile fabrics, and glue products of this kind could be prepared in Canada.

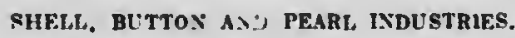

Mans years ago my attention was called by Professor Mavor, of the University of Torouto. to the value of sliplls. such an the large fresh water elam shells. which abound in the lakes and rivers of Ontario. Manitoba and the west. Many of these shells (Urio, Anadonta, \&c.), are probably too thin usually for profitable utilization, but there nre great supplies of suitable shells going to waste, which could be turned to profitable account. The importance of shell products in the United States is apparent from Mr. C. H. Stevenson's statement that 'nearly, if not quite, 1,000,00n tons are secured annually in the United States, consisting principally of the shells of oysters, clams, river mussels and a very much smaller quantity of other varieties. A 
fair valuation of theac at the places of consumption would doubtless amount to $\$ 1,500$,(m) ; to this should be added about $\$ 600,000$ an the value of penrls secured during the last year in the Missinsippi Valley and elsewhere. The value of the shclls securer ontaide of the United Staten, principally mother-of-penrl shells, amounts to $\$ 5,000,000$ or $\$ 6,000,000$ annually, and the pearls seeured sell for nearly an equal nmount. Pearls nre not seeured in the sen in such largo quantitics as formerly, but their vuluo is greatly inereased. The manufneturc of mother-of-pcarl and sweet-water shell in the form of buttons, buckles, knife-handles, pistol stoeks, fe., gives enploynient to nearly 10,000 persons in this eountry, and to probably three times that number in Furope ant elsewhere.'

'Th' shell tiade,' said Mr. Simmons thirty jears ngo, 'is growing year by year into gronter importance, and there is ample seope yet for its extension with profit and adrantuge, alike to the fisherman. the merehant aud importer, to the manufacturer and venter. and to the general public who aro purchasers. Leaviug out of account the euttle shell or cuttle fish bone which is ohtuinul from certain speeies of squid and is

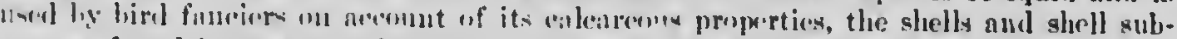
stances fouml in seas and rivers may he elassified as follows:-

(1) Shells suitable for white nnd pearl buttons.

(2) Shells nsed for omnunenting jewrl cases, faney boxes, nnd penrly or irideset $n$ t in appearnnce.

(3) Shells used for knife handles, spoons, Inmps, pipes, de.

(4) Shells adapted for eameo earving, braeclets and jewellery.

(5) Slells which enu be comverted into an euamel for pottery glazing.

(i) Shrllw wisd furrely us orunuruts when polished or as money anougst prumitive tribins.

In C'anindi "ur shell rosoureeg have heen left nimost unexploited while errtain waters in the I"nitel States owing to the demands for their shell produets linve been almost denurled. One authority of prominenee in Iowa has sounded reently a warn. ing note. Arcorling to the New York Fishing Gazelle, February 23, 1907, this anthority" "is secking to get fisls commission experts or other qualified cxperts of the governueut to muke a stuly of how best to propagate and distribute these mussels or elnms. II believes in this way some means can be found to pcrpetuate the supply
and sare the industry.

' Census figurcs show that in 1005 the value of the fresh water pearl button made in the United States was nearly $\$ 5,000,000$. Of this nmount New York was reeredited witl $\$ 1,813,16 \tau$, while Iown lial $\$ 1,500,949$. Iown had fifty-one factories, while New York only had twenty-six.'

The abalone or ear-shell industry is one eapable of development, for beds of these beautiful shells oeenr $\mathrm{n}$ : known points in British Columbia, and many undiseovered beds doubtless pxist. London imports from Japan from 76 to 100 tons of these earshells (Haliotis), while in California a valuable business has long existed. The following notice of this inclustry may be quoted, having reference particularly to the
fishery oll Terminal islnum. California:-

'When the scason is at its height twelve to fifteen tons of abalone are handled cacl week. They are taken from the shell, the intestines removed, and the muselrs boiled for canning and shipped to many points, or dried by steam preparatory to the use of the Japanese, Chinese and other Orientals.

- When the fish are removed the shells are saved. If imperfect, they are stowed arvay to be ground up for poultry food or for fertilizer. If perfect they are turned over to the California Pearl Manufacturing Company and from them are inade some of the most beautiful ornaments that could be imagined.

'Some are polished in their entirety and are sent to the curio and shell stores by the thousand. Manj are shaped for brooches, belt pints, cuff buttons, ear-rings, \&e., and in their changeable rainbow hues, rarying with each angle at which the light strikes them, form most beautiful and attractive novelties. Others are shaped for 
octtings for jewellery and large quantities are mounted in sterling silver for jewellers all over the country.

- The process of treatment is very interenting. First, the rough exterior is ground on the carborundum wheole. Next they are polished on the cloth wheel and later shaped for whatever purpose is desired.

- The market for these products is over widening. They are sold from Maine to Tampa and from cont to coast. It is a beautiful product and weem dentined to in. creasing popularity!'

The mother of pearl maferial when coarsely pulverized is used for ornamental decoration, eupecially letters in decorative sign painting.

In fishing ahell-fish for the various purposes referred to the fisheruan has always before him the possibility of finding pearls or gems of value." Not ouly the true mother of pearl shell, such as the Melcagrina or so-called pearl oyster of Ceylon; but uumerous other shell-fish yictd pearts, the Chinese river mussel beiun wetl-known in thie respect. The fresh water mussels, the sen-oyster, the West Indiau strounbus, the giaut Tridaena, and naany others produce pearls, while in the streuns of Britain. especially Scotland, pearls have tong been sought in the rirer clams or mussuds; but our Canadian lakes and rivers abound in shell-fish, which are known to produce thes: raluable gems. Some of our remote waters hare recently nequired fame on this ncenunt. The Chicago Examiner said, a fow months ngo:-

\section{'pearl fushifry is casadias wu.ds.}

'In the mighty streams flowing through Ungava, Canada, a profitable pearl industry is carried on amng the Indians und Eskimos, says tho Chicago Examiner. Barrenness and desolation, rocky shores beaten by an icy sea, long winters and short inclennent summers are the chicf eharacteristics of that northern land. Signs of human life are scarce there, but at intervals may be seell rude huts of rocks erected by whale and seal hunters long since departed for more profitable fields. In the rushing waters of the streams, which empty iuto the sea, nearts are found hidden in the shells of the mussels, which are often so plentiful as to partially block the river. Unlike the pearls of Ceylon, they are snowy whitc, but nevertheless of the finest quality, although a certain percentago are irregular in shape.

At the present time several hundred men are engaged in systematically hunting for the pearls. They collect the mussels and nile them in henps, where they are left until decomposed and then the pearls are essily extricted from the shells. Several large jewellery houses send travellers on periodical visits to buy these pearls, and, of cuurse, the IHudson Bay Company's traders get a fair share of the gems.'

It is impossible in this placo to deal in detail with such branches of a shcll-fish industry as the pearl business, or the utilization of the shells themselves; but it may be pointed nut that cmpty shells have a value in oyster eulture. They form the best. 'culteh' or rough flour on which oysters can he planted for breeding purposes. Quite good returns are secured from the empty shells, which are useless for buttons or other purposes. Scallop shelts are in demand and they bring rarely less than 6 cents per bushel.

\section{PRAWXS, CRAYFISH, ETC.}

In the future the utilization of shrimps, prawns, and other crustaceans will nn doubt be carried out on an extensive scale. They are abundant on the Atlantic and Pacific coasts, and on the latter coast, our Canadian waters abound in a variety of exceptionally fine edible speries. A limited prawn and shrimp fishery is pursued; - It Was announced recelutly in the press that a prarl obtained in the Miami River,
Ohlo, sold for $\$ 2.800$ this season. 
but the development of a eanning induatry would enable these dainty ' aboll-fish' to be seat to markets all over the Dominion. In Florida and in Califormia canned chrimpe and prawne form an Important artlele of trade.

The incrodlbls abundant aupplles of lobsters on the Atlantlo conet of Canada rendered unimportant the creation of a shrimp or prawn finhery; and they atill form an unutllised finbers rewoures.

In our frewh waters them oceur numerona apecies of small frmh-wator lobntem or cray-fich, often erroneoubly called 'craw-fich', wherean the 'craw-fish' is a very large cruataceas found in the aea and remembling a lobater of unuaual size, and of a piny exterior. For atreama or lake in Canara do not abound in craj-fish; but there has hithertn been little or no deinand for them as a marketable product.

Profeseor F. A. Andrews meentl, dealt prett, full. with the arajhh questlon and the posslbllity of a future crasfish fiahery. He anys:-

The demand should Increane, with the arowth of commopolitan populatinn that appreciate such food 2 is used in Furope, with the mrowth of large populatlona too remote from the sea coast to obtain fresh sca food. and with the increasing inarlequacy nf the marine crustacea to aupply the needs of even those consumers who dwell near an food. Thus the lobster lndustry has been atrained tlll the use of young specimens

- No doubt in time the the exterminated large nnes has become very ext.neive. industry wlll tend to the demard for craysish will exceed the natural supply and this clam and many more important faheretrograde course as that of ths lobster, oyster. rants legialative untrol and fiaheries till the real value of the crayfish as food wnrof more and more of our ons alone make posible the continunuce

"Soonar or lateen "inexhaustlble" food supplies.

to legislative restriction supply of crayfish will need to be made greater. In addition able for trial when the suppls becomes deficient, or, if on is ill other fisheries, now ing of native species in the aupply becomes deficient-first, the artificial breedof better apecies than those naturally and flavour by culture and cross-brending.

- Trperimento in

artificially. They grew to laboratory have ahown the practicability of rearing crayfish able size-three inches-at the end of the second in three yearm, and were of marketof crayfish reaching maturity end of the recond year from the egr. The proportion from proper culture large individual than might be expected in such cases, and

The large weatern Oregon large races might be obtained. artificial conditions to length of brer is of rapid growth and grows under from eggs hatch in the spring eastern or the southern varieties, This large species sells for twice the price of the vantage of a more attractive and and besides its larger size and weight it has the adthe east should be most a that its introduction into in the laboratory were asect, the specimens brought here and kept alive if these crayfish were available an the six-inch "short lobster" now used as food, and young lobsters and thus protect the

The third method of the lobster industry. larger races-may remain for later m the available food supply-the origination of of species of crayfish in this and the industry, but considering the number some future production of

- Apropos of the matter of introducing crossing and selcction. teresting to know that a similar thing ing the Oregon variety into the east, it is inand Switzerland, where the crayfish of jears, the native varieties have ing the streams and preserves with the American and the governments are suw stock- 
In Canada the supplies of eraysioh are co great that the maln queation la not how to Improve theas in vize or quantity, but how to turn to sccount the abundent supplles
which we pases.

A ghrimpins or

small mahed bes of net pushed or involving the use In most countrles of a peculiar these oreature llo la a danger to more veluable the sandy or eravelly shores where

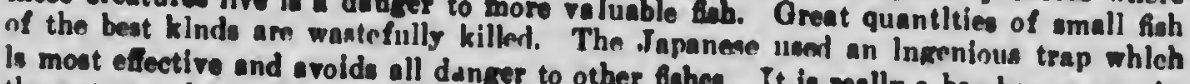
the entrance in a funnel-ahapert plese with it fahea. It is really a bomboo cage. At o that any shrimp that bas once entered it can ant and projecting Intn the Interior. dozens of these trapu are tied to Paludina) are put within each; then the rhole and crushed shell-fish (Corbicula or out from tlme to time and the shrimps are secured.

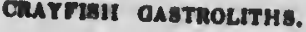

Two peculiar button-like siones are formed in the fore part of the stomach of the crayfioh during the late summer, according to M. Chantron, about forty days before the eyea,' as they were culled, were held in these sastrolith, of stomach stones, or 'crab's orders, and in Chlna and Japan in great repute a a remeds acainst vurious disthem. They bring a vers bigh price ow miraculous properties are still attributed to limy buttons are not to be confused ning to thelr alleged curative properties. Thene masticatory portlon of the stomack, and their purd teeth of the 'gastric mill' or hind careou natter for the new shell. in the stomach and in three or four days they as these stonelike buttons are found

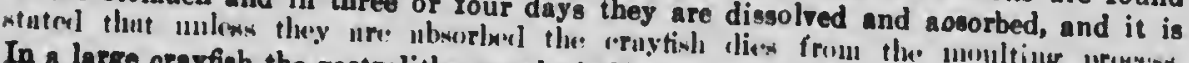
In a larce crayfinh the gastrolith may be hale an in from the munltink preswas. an inch in thickness, alld arc of a smooth chalks inch in diameter, about one-third of with aome lime phosphate, a little sodeth chalky substance, chiefly carbonate of lime, these rounded buttons is aitach at the and a proportion of animal matter. Each of a orayfish fishery devoluped, the ccllection of the thomach in ite ant urior part. Were be scmunerative, as frequent inquiries of these gastrolitha in the late summer would as to where amall quantities can be obtained in Canada.

SKINS OF FISHES, WHALES, ETC. It is impossible in thin report to dwell upon the somewhat complex and varicd unes
of the skins of fishes and aquatic animals. The skins of the porpoise, beluga or white
whale and similar sea creatures, can be converted into the for whale and similar sea creatures, can be converted into the finest kinds of leather. The of beluga leather, which was fine-grained, texible, unbly fine samples some years aro Mr. C. H. Stevenson, the eminent specialist unbrcakable and most durablc. As marine resources, has said:-

- Leather is marle froun the

of the apecies of fish, but these rank practically all the aquatic animals, and of most is produced in largen quantities. rank among novelty or fancy leathers. Seal leather hest of all skins for leather purposes hide of the beluga, or white whale, is one of the bility. It is sold as porpoise leather. Tamed walrus hides, are in great demand for polishing wheels and other hides, especial t'ie thick ones, aquatic skins used to a less extent for leather purposhanical purpe Among the porpoise, sea elephant and a rery largn rariety of fishoses may be men'ioned sea lion.

The soft elastic skin of the whale siets of fish skins, especially thosc of sharks. the abundant connectire tissue in it, can bo pickled tribe, rich in gelatine owing to 
the most prized dainties in Greenland and is pronounced excellent by those who have partaken of it.'

\section{ICE MANUFACTURE.}

It may not appear very pertinent in a report on fishery products in Canada, which are not utilized, to make any reference to such an industry as the production of ice. There is, however, an appropriateness in introducing here this matter, not only because those engaged in the fishery business use ice rery largely; but they are located, as a rule, where the development of an ice manufacturing industry would be easy and profitable. The abundance of ice along our Canadian shores on the Atlantic invites enterprise on the part of ûsh firms on a more extensive scale than it has hitherto reached. Large cities in the United States, such as New York, Boston, \&c., require an almost unlimited supply. There is no duty on icc, and small shippers might find it profitable to ship cargoes late in the winter before warm weather begins, although if shipped in the usual way the cost of freight is too heavy, viz., $\$ 1.50$ per ton to New York. Last year and the year before, New Brunswick and Nova Scotia schooners carried single shipments of 150 or 200 up to 600 tons. There is considerable waste (about 40 per cent) under present conditions of transit; but if the United States demand be favourable, there are substantial returns to small shippers who can freight ice at cheap rates on schooners.

\section{CONCLUSION.}

In the foregoing notes, which do not pretend to be more than a rapid survey of salient features of this important question, the waste of valuable fish by-products, the production of oil, and the manufacture of fertilizer or manure has been omitted. Two reasons afford an explanation of this omission, viz.: the extent of these questions which is so great that lengthy reports on each would be necessary, and second, the fact that oil and fertilizer industries are already being carried on, perhaps to a very inadequate extent; but on a sufficient scale to show that the value and importance of these waste products are not being ignored in Canada. 


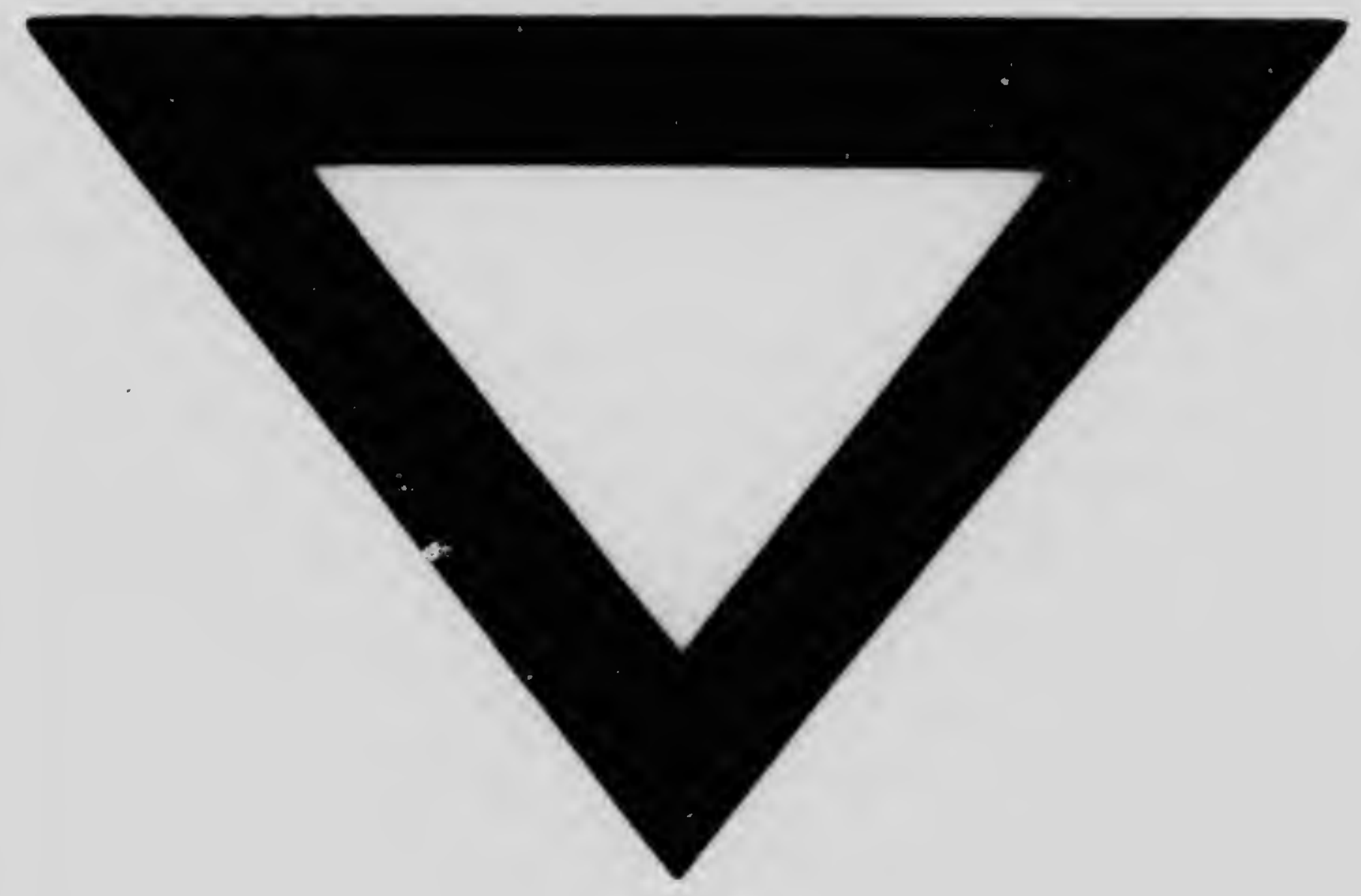

